\title{
Review-Bipolar Plates for the Vanadium Redox Flow Battery
}

\author{
Barbara Satola ${ }^{\mathrm{z}}$ (i)
}

Deutsches Zentrum für Luft- und Raumfahrt e.V. (DLR), Institut für Vernetzte Energiesysteme, 26129 Oldenburg, Germany

Bipolar plates are one of the key components of vanadium redox flow batteries. They electrically conduct and physically separate adjacent cells in series and provide structural support to the stack. Bipolar plates are exposed to harsh conditions due to the acidic vanadium electrolyte and high potential differences which occur in vanadium redox flow batteries. Therefore, the material needs to fulfil good electrical conductivity, sufficient impermeability and mechanical stability as well as long-term chemical and electrochemical resistivity. This review provides a comprehensive overview of carbon-polymer based composites which are preferentially applied for bipolar plates in the vanadium redox flow battery. It addresses the composite materials, their production, properties, degradation mechanisms, designs and costs. In addition, it covers challenges and potentials for further development and optimization.

(C) 2021 The Author(s). Published on behalf of The Electrochemical Society by IOP Publishing Limited. This is an open access article distributed under the terms of the Creative Commons Attribution 4.0 License (CC BY, http://creativecommons.org/licenses/ by/4.0/), which permits unrestricted reuse of the work in any medium, provided the original work is properly cited. [DOI: 10.1149/ 1945-7111/ac0177]

Manuscript submitted December 2, 2020; revised manuscript received April 28, 2021. Published June 2, 2021.

The vanadium redox flow battery (VRFB) is a promising stationary energy storage technology which can be applied to balance fluctuating energy from renewable energy sources. The construction of flow batteries with their separate reaction unit and external storage tanks enables to scale up power output and energy storage capacity independently for different demand. For battery operation, the electroactive species are pumped through the reaction unit. The electrolyte is usually composed of vanadium ions with a concentration of 1.5 to $2.5 \mathrm{~mol}^{-1}$ which are dissolved in 1.5 to 3 mol $1^{-1}$ sulfuric acid. $^{1-5}$ The negative electrolyte contains $\mathrm{V}^{2+} / \mathrm{V}^{3+}$ ions and the positive electrolyte is composed of $\mathrm{VO}^{2+} / \mathrm{VO}_{2}{ }^{+}$ions. The corresponding redox reactions are displayed with the following equations (Eqs. 1.1-1.3). In general, VRFBs are operated at current densities between 50 and $200 \mathrm{~mA} \mathrm{~cm}^{-2}$. 3,6,7 The formal potential of a single cell is approximately $1.4 \mathrm{~V}$, since the standard OCV of $1.26 \mathrm{~V}$ needs to be corrected for real VRFB single cells due to the Nernst's factors. ${ }^{6}$

$$
\begin{aligned}
& \text { Positive half-cell } \mathrm{VO}^{2+}+\mathrm{H}_{2} \mathrm{O} \rightleftharpoons \mathrm{VO}_{2}^{+}+2 \mathrm{H}^{+}+\mathrm{e}^{-} \\
& E^{0}=+1.00 \mathrm{~V} \text { vs } S H E
\end{aligned}
$$

Negative hall-cell $\quad \mathrm{V}^{3+}+\mathrm{e}^{-} \rightleftharpoons \mathrm{V}^{2+} \quad E^{0}=-0.26 V$ vs $S H E$

Overall reaction $\mathrm{VO}^{2+}+\mathrm{V}^{3+}+\mathrm{H}_{2} \mathrm{O} \rightleftharpoons \mathrm{VO}_{2}^{+}+\mathrm{V}^{2+}+2 \mathrm{H}^{+} \quad U=1.26 \mathrm{~V}$

In a single cell setup the reaction unit contains two carbon felt electrodes separated by a membrane. The redox reactions take place within the respective half-cells. The electrons that are released by the electron transfer reactions are transported by end plates in the through-plane direction to the current collectors, such as copper plates, which are connected to a load/source, while charge balance is provided by ion migration through the membrane. ${ }^{1,2,5,8-11}$ By stringing together a defined number of single cells in series by means of bipolar plates (BPPs) one can obtain a battery stack in order to increase the overall battery voltage and power (Fig. 1). ${ }^{1,6,12}$

In this context, BPPs are one of the key components for construction of VRFB stacks. BPPs are employed in order to physically separate adjacent cells from each other, to provide structural support to the stack and to electrically connect the single cells in series. ${ }^{10,13,14}$ Thus, important characteristics of BPPs include high electrical conductivity, electrochemical stability in the applied

${ }^{\text {z} E-m a i l: ~ b a r b a r a . s a t o l a @ d l r . d e ~}$ medium in a wide potential window, mechanical integrity and impermeability of electrolyte through the compact BPP structure. $^{2,15-17}$ Therefore, the selection of proper materials for BPPs is an important issue. Figure 2 summarizes different materials for BPP manufacturing in fuel cell applications ${ }^{18}$ which might be also applicable in redox flow batteries.

Although many metals have a very good electrical conductivity they are not necessarily appropriate as BPP material. Metals without a protective coating layer do not provide the necessary chemical stability in the acidic electrolyte of VRFBs. ${ }^{14,18-20}$ For instance, a BPP for the VRFB composed of nanotubular $\mathrm{TiO}_{2}$ on Ti substrate which was coated with an $\mathrm{IrO}_{\mathrm{x}}$ layer resulted in comparable good voltage and energy efficiencies, high electrocatalytic activity and high corrosion resistance. ${ }^{21}$ Nevertheless, graphite is more convenient as material for BPPs since it is conductive and possesses a high electrochemical and chemical stability in acidic environment. ${ }^{18,22}$ However, pure graphite substrates suffer from brittleness and electrolyte penetration due to their porosity. Therefore, graphite plates require a certain thickness to overcome their drawbacks resulting in larger volume, higher weight and cost. ${ }^{4,17,18,23,24}$ Conductive carbon-polymer based composites are usually favored as materials for the production of BPPs since they combine many advantages in comparison to pure graphite plates such as lower cost and weight and better mechanical strength, tightness to electrolyte permeation and corrosion resistivity. ${ }^{2,20,25}$

Since a variety of composite materials with different characteristics were already developed and investigated, the purpose of this review is to summarize relevant literature and provide a comprehensive overview about material properties, design development, financial aspects as well as corrosion occurrence of carbon-polymer based composite BPPs for the VRFB.

\section{Composite Bipolar Plates}

Components.-The choice of proper materials for the BPPs production has a strong influence on the properties of the plates such as electrical conductivity, mechanical stability, permeability, performance, costs and electrochemical resistance to ensure a long cycle life. 26,27

BPPs for VRFBs are usually composed of carbon-polymer based composite materials. The carbon components provide the necessary electrical conductivity. Raw materials such as graphite fibers and powders are usually used as major conductive components. In some cases carbon black, carbon nanotubes, exfoliated graphite and others can be applied as minor or major fillers to provide improved conductivity to the composite material (Table I). ${ }^{2,4,15,16,19,20,28-32}$ The term "graphite" covers a variety of different graphite types and the origin of graphite might differ. For instance, pyrolytic graphite is 


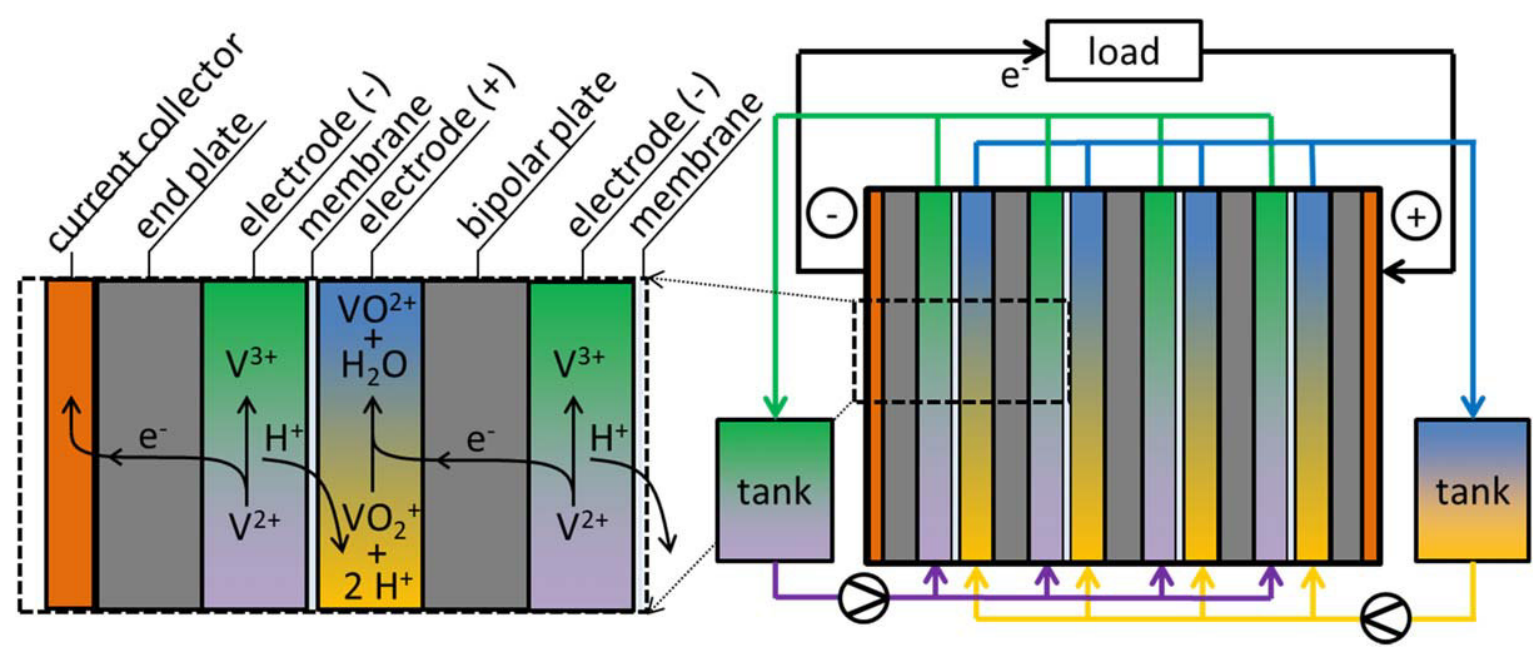

Figure 1. Schematic overview of a VRFB stack during discharge mode containing four cells (right) and a zoom-in section showing the vanadium redox reactions in both half-cells as well as proton and electron transport through membrane and BPP, end plate and current collector, respectively. End plate, BPP that is flanking the stack; electrode $(-)$, negative half-cell electrode; electrode $(+)$, positive half-cell electrode.

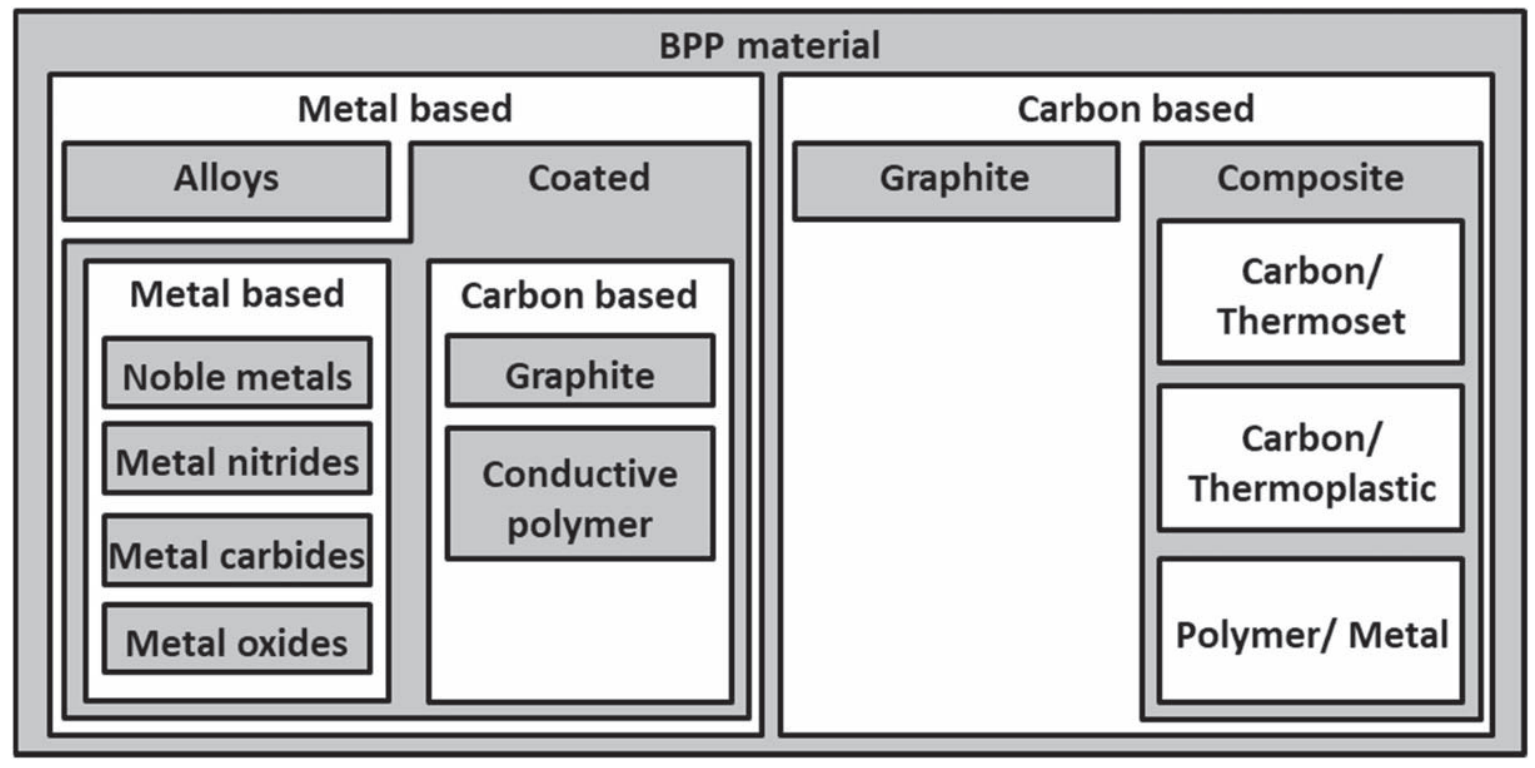

Figure 2. Summary of BPP materials for fuel cell applications ${ }^{18}$ and redox flow batteries.

characterized by graphene sheets that are crystallized in a planar direction, kept together by van der Waals bondings resulting in a highly oriented structure with good mechanical properties. Expanded flaketype graphite, however, contains randomly aligned graphite particles leading to worse mechanical strength. Thus, natural graphite, pyrolytic graphite and highly oriented pyrolytic graphite can provide different electrochemical properties. ${ }^{24}$ Also the electrical conductivity and processability of the graphite material depend on its morphological shape and relative content within the BPP. Generally, spherically shaped graphite provides better processability than flake-shaped graphite. $^{33,34}$ The raw materials need to fulfill high quality requirements such as defined particle size distribution and shape as well as purity. ${ }^{33}$ Contamination of graphite components with metal particles can lead to release of metal ions into the electrolyte which can have an influence on the electrochemical performance and lower the overall power density of the VRFB. ${ }^{33,35}$

The polymer or binder matrix, respectively, is usually composed of thermoplastic or thermoset polymers such as polypropylene, polyethylene, fluoroelastomer, polyphenylene sulfide, diverse rubbers (butyl rubber, ethylene-propylene rubber, ethylene-propylene diene monomer rubber, nitrile rubber), styrene-ethylene-butylene-styrene elastomer, nylon, epoxy or phenolic resin (Table I). ${ }^{4,15,16,19,25,28-32,40,43,52}$ For selection of the appropriate polymer, the (melting) temperatures need to be taken into account, e.g. polypropylene can be used up to $90{ }^{\circ} \mathrm{C}$ while polyvinylidene fluoride (PVDF) based BPPs could be operated up to $120{ }^{\circ} \mathrm{C}^{33}$ However, since the operation temperature of VRFBs is anyhow limited to a range of approximately $10{ }^{\circ} \mathrm{C}-40{ }^{\circ} \mathrm{C},{ }^{1,53}$ the temperature stability of the polymer is usually not the main obstacle. More important is the (electro)chemical stability and the processability of the composite materials. Thermoset polymers, such as phenolic resin, change their chemical structures while they are heated and processed. In contrast, thermoplastic materials like PVDF and polypropylene can be reversibly heat-treated and processed. Thus, BPPs with thermoset phenolic resin, for example, are difficult to process but they have a good electrical conductivity, mechanical and chemical stability. ${ }^{33}$

The ratio of the major conductive component, such as graphite, is usually around $80 \mathrm{wt} \%$. Sometimes further minor bridge material 
Table I. Composition and fabrication process of carbon based composite BPPs for the VRFB.

\begin{tabular}{|c|c|c|c|c|c|}
\hline No. & Literature & Conductive compound & Binder material and curing agent & Fabrication method & Remark \\
\hline 1. & $\begin{array}{l}\text { Nam et al. } \\
2017^{15}\end{array}$ & $\begin{array}{l}0.12 \mathrm{~mm} \text { thick plane weave carbon } \\
\text { fiber fabrics (WSN 1k, SK } \\
\text { Chemicals, Korea), nano-size } \\
\text { carbon black (Ketjen black } \\
\text { 600JD, Mitsubishi Chemical, } \\
\text { Japan) }\end{array}$ & $\begin{array}{l}\text { Fluoroelastomer, curing agents } \\
\text { (bisphenol, magnesium oxide } \\
\text { and calcium hydroxide)(Dai-El } \\
\text { G327, Daikin, Japan) }\end{array}$ & $\begin{array}{l}\text { Carbon fiber fabrics wetted with } \\
\text { mixture of carbon black parti- } \\
\text { cles }(1,2,3,4 \text { and } 5 \mathrm{wt} \%) \\
\text { dispersed in fluoroelastomer/ } \\
\text { acetone solution. Two plies } \\
\text { stacked, hot compression } \\
\text { molding }\left(20 \mathrm{MPa}, 220{ }^{\circ} \mathrm{C},\right. \\
20 \text { min) between soft-layers of } \\
\text { fluorinated ethylene propylene } \\
\text { films. }\end{array}$ & \\
\hline 2. & $\begin{array}{l}\text { Lee et al. } \\
2017^{36}\end{array}$ & Non-woven carbon felt & $\begin{array}{l}\text { Film type epoxy adhesive (K51, } \\
\text { SK Chemicals, Korea) }\end{array}$ & $\begin{array}{l}\text { Impregnating film type epoxy ad- } \\
\text { hesive into carbon felt. Hot } \\
\text { compression molding }(1,2,3,4 \\
\left.\text { or } 5 \mathrm{MPa}, 150{ }^{\circ} \mathrm{C}, 30 \mathrm{~min}\right) \\
\text { using a soft-layer of fluorinated } \\
\text { ethylene propylene film } \\
\text { (A4000V, Airtech, United } \\
\text { States) between laminate and } \\
\text { mold. }\end{array}$ & \\
\hline 3. & $\begin{array}{l}\text { Minke et al. } \\
\text { 2016, Satola } \\
\text { et al. 2016, } \\
2017, \\
2018^{33,37,38,3-} \\
9\end{array}$ & Graphite & Polypropylene & $\begin{array}{l}\text { Extruding } 86 \% \text { graphite and } 14 \% \\
\text { polypropylene, injection } \\
\text { molding, sandblasting. }\end{array}$ & $\begin{array}{r}\text { Commercial (PPG86, Eisenhuth } \\
\text { GmbH \& Co. KG, Germany) }\end{array}$ \\
\hline 4 & Li et al. $2016^{25}$ & Expanded graphite plate & $\begin{array}{l}\text { Alcohol soluble phenolic resin } \\
(15 \%, 20 \% \text { or } 25 \%) \text { or water- } \\
\text { soluble phenolic resin }(25 \%)\end{array}$ & $\begin{array}{l}\text { Phenolic resin pumped into gra- } \\
\text { phite plate under vacuum con- } \\
\text { ditions }(-0.09 \mathrm{MPa}, 5 \mathrm{~h}) \text {. } \\
\text { Removing resin on surface with } \\
\text { ethanol. Drying }\left(40{ }^{\circ} \mathrm{C}, 5 \mathrm{~h} ; 60\right. \\
\left.{ }^{\circ} \mathrm{C}, 5 \mathrm{~h} ; 80^{\circ} \mathrm{C}, 5 \mathrm{~h}\right) \text { and hot } \\
\text { compression molding }\left(130{ }^{\circ} \mathrm{C} \text {, }\right. \\
1 \mathrm{~h}) .\end{array}$ & \\
\hline 5 & Liu et al. $2015^{40}$ & Carbon & Polyethylene & & $\begin{array}{l}\text { Commercial (ChaoYang } \\
\text { HuaDing Energy Storage } \\
\text { Technology Co., China) }\end{array}$ \\
\hline 6 & $\begin{array}{l}\text { Zhang et al. } \\
\qquad 2015^{30}\end{array}$ & $\begin{array}{l}\text { Carbon black (Ensaco350G, } \\
\text { Timcal Belgium S.A., } \\
\text { Switzerland) and/or carbon fiber } \\
\text { (Nantong shenyou carbon fiber } \\
\text { Co., China) }\end{array}$ & $\begin{array}{l}\text { Polypropylene elastomer } \\
\text { (Vistamaxx 6202) with small } \\
\text { amount of vinyl monomers re- } \\
\text { ndomly inserted into main chain } \\
\text { (ExxonMobil Chemical Co.), } \\
\text { polypropylene (K8303, Beijing } \\
\text { Yanshan Petrochemical Co., } \\
\text { Ltd.), }\end{array}$ & $\begin{array}{l}\text { Mastication of polypropylene } \\
\text { elastomer }\left(80{ }^{\circ} \mathrm{C}, 3 \mathrm{~min}\right) \text {, } \\
\text { adding polypropylene and mas- } \\
\text { tication }\left(170{ }^{\circ} \mathrm{C}, 5 \mathrm{~min}\right) \text {, adding } \\
\text { conductive fillers and mastica- } \\
\text { tion }(3 \mathrm{~min}) . \text { Mixed compounds } \\
\text { stored at room temperature } \\
(24 \mathrm{~h}) . \text { Hot compression } \\
\text { molding }\left(10 \mathrm{MPa}, 20{ }^{\circ} \mathrm{C}\right) \text {. }\end{array}$ & \\
\hline 7 & $\begin{array}{l}\text { Lee et al. } \\
2015^{41}\end{array}$ & Carbon & Epoxy & $\begin{array}{l}\text { Carbon/epoxy prepregs stacked, } \\
\text { hot compression molding }\end{array}$ & \\
\hline
\end{tabular}


Table I. (Continued).

No.

Literature

Conductive compound

Binder material and curing agen

Epoxy

$2015^{42}$

Carbon

$2015^{42}$

Choe et al. 2015

(Choe et al.

2016) ${ }^{43}\left({ }^{44}\right)$

SK Chemical, Korea), carbon

black (Ketjen black 600JD,

Mitsubishi Chemical, Japan

Carbon, pyrolytic graphite foils

Samjung CNG, Korea)

Kim et al.
$2014^{14}$
phite foil

Fabrication method

$\left(20 \mathrm{MPa}, 130{ }^{\circ} \mathrm{C}, 1 \mathrm{~h}\right)$ using

liquid-type mold release

(Safelease30, Air tech, United

States) for demolding.

Carbon/epoxy weave prepreg

cure-triggered (0.6 MPa, $105^{\circ}$

$\mathrm{C})$, cooled $(0.1 \mathrm{MPa})$ and post-

cured $\left(0.1 \mathrm{MPa}, 60{ }^{\circ} \mathrm{C}, 6 \mathrm{~h}\right)$.

Two plies of carbon/epoxy weave

prepregs stacked with expanded graphite coating layer. Hot

compression molding (10 MPa, $80{ }^{\circ} \mathrm{C}$ for $1 \mathrm{~h}, 125^{\circ} \mathrm{C}$ for $2 \mathrm{~h}$ ).

Cooled to room temperature.

Development of corrugations in

the central area of BPP. (with

shape optimization ${ }^{44}$ )

Polyethylene powder (UR644,

Lotte Chemical, Republic of

Korea)

Polyethylene 2 wt $\%$ carbon black mixture uniformly applied on carbon fabric using a sieve. Hot compression molding $\left(160^{\circ} \mathrm{C}\right.$,

$30 \mathrm{~min})$. Cooled to room temperature $\left(20 \mathrm{MPa}, 25{ }^{\circ} \mathrm{C}\right.$, in

$2 \mathrm{~h}$ ). (Then hot compression molding $\left(1.2 \mathrm{MPa}, 160^{\circ} \mathrm{C}\right)$ of a sandwich of a polyethylene/

carbon composite BPP in be-

tween two carbon felt electrodes

to join the components to an

assembly).

Two plies of carbon/epoxy prepregs stacked and pyrolytic graphite attached on both sides.

Hot compression molding

$\left(20 \mathrm{MPa}, 125^{\circ} \mathrm{C}, 1 \mathrm{~h}\right.$ )

Two plain-weave carbon/epoxy prepregs stacked between graphite foils. Hot compression molding $\left(80{ }^{\circ} \mathrm{C}, 30 \mathrm{~min} ; 120^{\circ}\right.$ C, $60 \mathrm{~min}$ ) using silicon rubber and demolding layer. Surface crack closing procedure with a roller by applying a compaction pressure (optimal $\geqslant 12 \mathrm{MPa}$ ).

Two sheets of plain weave type

carbon prepreg stacked with expanded graphite foil by means
Remark

Commercial carbon/epoxy pre-

preg (USN020, SK

Chemicals, Korea)

Commercial carbon/epoxy prepreg (WSN1k, SK

Chemicals, Korea)

Commercial carbon/epoxy prepreg (WSN1k, SK

Chemicals, Korea)

BPP-electrode assemblies

Commercial carbon/epoxy prepreg (WSN1k, SK

Chemicals, Korea) and commercial pyrolytic graphite foils

Commercial carbon/epoxy prepreg (WSN 150 1k, SK

Chemicals, Korea) and commercial pyrolytic graphite foils (BD-100, Samjung CNG, Korea)

Commercial carbon prepreg (WSN150, SK Chemicals, Korea) 
Table I. (Continued).

\section{Caglar et al.} $2014^{29}$

Synthetic graphite (KS5-75TT, Timcal Graphite \& Carbon), multi-wall carbon nanotubes (Nanocyl, Belgium)

Natural, spherical and artificial graphite flakes, Ketjenblack carbon, exfoliated graphite, carbon fiber $2013^{24}$

Lee et al. $2012^{17}$
Synthetic graphite (KS5-75TT, Timcal Graphite \& Carbon), multi-wall carbon nanotubes (NC7000, Nanocyl, Belgium)

Expanded graphite

Graphite (Morgan, Korea), carbon black (Super-P)

Flexible graphite BPP (Cathay Packing \& Sealing Co Ltd.) graphite powder (Shanghai colloid chemical plant), carbon black (Vulcan XC-72 R, Carbot) Graphite, USA)
Polypropylene (HL508FB,

Borealis), montan wax

(Licocene OP, 1-methyl-1,3propanediyl ester, Clariant)

Aromatic epoxy of diglycidyl ether of bisphenol A (Sigma Aldrich), curing agent diaminodiphenyl sulfone (Sigma Aldrich)

Polyphenylene sulfide powder (Ryton V-1, Chevron Phillips), Titanium IV 2-propanolato, tris isooctadecanoato-O coupling agent (KR-TTS, Kenrich Petrochemicals, Inc.)

Fluoropolymer

Epoxy resin (Tohto Kasei), hardening agent (TAMANOL 758, Arakwa Chemical), hardening accelerator (Triphenyl-phosphine, Arkema)

Thermo-plastic phenol formaldehyde resin (Tianjin resin factory), hexamethylene tetramine (Shenyang fifth reagent factory)

High density polyethylene powder (GA 7260H, Kemcor Australia), of hot compression molding ( 80

${ }^{\circ} \mathrm{C}, 30 \mathrm{~min} ; 120{ }^{\circ} \mathrm{C}, 60 \mathrm{~min}$ )

using silicon rubber and de-

molding layer.

Polypropylene, conductive fillers and wax (different composi-

tions) melt mixed to granulates. Injection molding (feeding with $900-1800$ bar, $50{ }^{\circ} \mathrm{C} ; 200^{\circ}$ $\left.\mathrm{C}-230^{\circ} \mathrm{C} ; 240^{\circ} \mathrm{C}\right)$.

Melt mixing $\left(80^{\circ} \mathrm{C}\right)$ of epoxy with curing agent. Adding conductive fillers and stirring $(1 \mathrm{~h})$, drying $\left(60{ }^{\circ} \mathrm{C}, 24 \mathrm{~h}\right)$, hot compression molding (40 MPa, 200 ${ }^{\circ} \mathrm{C}, 1 \mathrm{~h}$ ), cooling to room temperature.

Polymer mixed with coupling agent ( $8 \mathrm{~min}, 1000 \mathrm{rpm}$ ), adding different amounts of conductive fillers and mixing, obtaining granulates. Injection molding $\left(140{ }^{\circ} \mathrm{C}, 345^{\circ} \mathrm{C}, 340{ }^{\circ} \mathrm{C}, 330^{\circ}\right.$ C)

Manufactured by reel-to-reel pro-

All components mixed (2 min) in defined ratios with varying carbon black content (79-x:

y:13:7:1 graphite:carbon black: resin:hardening agent:hardening accelerator). Hot compression molding $\left(100 \mathrm{kgf} \mathrm{cm}^{-2}, 100^{\circ} \mathrm{C}\right.$ $10 \mathrm{~min} ; 200 \mathrm{kgf} \mathrm{cm}^{-2}, 190{ }^{\circ} \mathrm{C}$, $40 \mathrm{~min})$.

Mixing (500 rpm, $5 \mathrm{~h}$ ) of phenol formaldehyde resin:hexamethylene tetramine:graphite powder: carbon black (2:0.2:1:1)

Dispersing in ethanol (15 min) and pouring in mold frame on graphite BPP (ethanol evaporation, $60{ }^{\circ} \mathrm{C}$ ). Heat bonding of adhesive conducting material to BPP $\left(150{ }^{\circ} \mathrm{C}, 30 \mathrm{~min}\right)$.

High density polyethylene powder, alkathene and alkatuff
Commercial (SIGRACET TF6, SGL, Germany)
BPP-electrode assemblies

BPP-electrode assemblies 
Table I. (Continued).

\section{Kazacos}

$2002^{23}$

Haddadi-Asl et al. $1995^{16}$

Kazacos \&

Skyllas-

Kazacos

$1989^{4}$

$2016^{33}$

Minke et al.

$2016^{33}$

Liao et al.

$2019^{31}$
Carbon black (Vulcan XC72,

Cabot Corp., USA and Degussa

Co., USA), graphite fiber

(Kureha Co. Ltd., Japan)

Graphite

Graphite

Graphite

Graphite powder, graphene

(Suzhou Tanfeng Graphene

Technology Co. LTD.), carbon

fibers extruded high density polyethy-

lene (E-Plas Pty, Australia),

extruded low density polyethy-

lene (E-Plas Pty, Australia), al-

kathene and alkatuff low density

polyethylene (WSM 168, WRM

124 and 710 UV, Orica

Polythene, Australia)

Polypropylene (LZM60CR, ICI Ltd. Australia), thermoplastic elastomer (SEBS, Keraton,

Shell Co., Australia), butyl rubber (Exxon Chemicals Australia), ethylene-propylene rubber, ethylene-propylene diene monomer rubber (EPR and EPDM, Vistalon, Exxon Co., Australia), nitrile rubber (NBR, Nipol, Polysar,

Australia), isobutylene-co-high density polyethylene (BMX42, ICI Co., Australia)

Polyethylene

Polyvinylidene fluoride (PVDF)

Phenolic resin (PF)

Epoxy thermosetting resin (Jiangyin Rongshun Chemical Co., LTD.) low density polyethylene separately pressed to sheets by hot compression molding

$\left(43 \mathrm{~kg} \mathrm{~cm}^{-2}, 135^{\circ} \mathrm{C}-155^{\circ} \mathrm{C}\right.$,

$10 \mathrm{~min}$ ). Heat-bonding of graphite felt sheets to both sides of each polymer sheet/material $\left(2.2 \mathrm{~kg} \mathrm{~cm}^{-2}, 155^{\circ} \mathrm{C}\right.$, various times) to form BPP-electrode assemblies.

Mixing polypropylene with single rubber components $(5 \mathrm{~min}$ ) and subsequently with carbon black (10 min), adding graphite fiber (range of times and tempera-

tures). Hot compression molding $\left(225 \mathrm{~kg} \mathrm{~cm}^{-2}, 200{ }^{\circ} \mathrm{C}\right.$, $30 \mathrm{~min}$ ).

Compression molding with $80 \%$ graphite.

Compression molding with $80 \%$ graphite.

Preparation of graphite mixture (20 wt \% graphene, $80 \mathrm{wt} \%$ graphite). Adding epoxy to different amount of graphite mixture $(9.4 \mathrm{wt} \%, 12.5 \mathrm{wt} \%$,

$15.6 \mathrm{wt} \%$ and $18.7 \mathrm{wt} \%)$

Adding of carbon fibers

(1.25 wt $\%, 2.5 \mathrm{wt} \%, 3.75 \mathrm{wt} \%$, $5 \mathrm{wt} \%$ ) to epoxy/graphite mixture $(18.7 \mathrm{wt} \%)$. Pressing mixtures to BPPs. Carbon coating.

Carbon fiber/epoxy prepregs stacked between $0-5$ polyester fabrics. Compression molding
(BPP-electrode assemblies in VRFB test measurement)

Commercial (BMA5, Eisenhuth GmbH \& Co. KG, Germany) Commercial (BBP4, Eisenhuth GmbH \& Co. KG, Germany) prepreg (thickness $20 \mathrm{~mm}$ ) (USN-020 A, SK Chemicals, Republic of Korea) 
Table I. (Continued).

\section{Liao et al.} $2020^{49}$
Graphene (Suzho Tanfeng Graphene Technology Co., Ltd.), carbon fibers $(3 \mathrm{~mm}$, Cangzhou Liyang New Material Co., Ltd.), graphite powders with $99 \%$ purity

Carbon felt $(2 \mathrm{~mm}$ and $5 \mathrm{~mm}$ thickness, Sichuan Rui-Sheng Carbon Felt Co., Ltd.), carbon nanotubes (CNT, C-Nano technology Ltd. and Beijing DK S\&T Ltd.), flaked graphite (Ø $1 \mu \mathrm{m}$, Qingdao TianYuanDa graphite Co., Ltd.)

Carbon felt (thickness $2 \mathrm{~mm}$ Runsheng Graphite Felt Co. Ltd.)

Graphite plate (Dalian Longtian Technology Co., Ltd., China), graphite powder (Shanghai

Rhawn Chemical Technology Co., Ltd.),
Polyethylene (100mesh, Suzhou Haolei Plastic Chemical Co., LTD.)

Detaching polyester fabrics.

Mixing $10 \mathrm{wt} \%$ graphene with

$90 \mathrm{wt} \%$ graphite powder.

Blending of different amount of

graphene/graphite mixture

$(15 \mathrm{wt} \%, 20 \mathrm{wt} \%, 25 \mathrm{wt} \%$ or

$30 \mathrm{wt} \%$ ) with polyethylene

powder. Adding different

amount of carbon fibers (5 wt\%,

$10 \mathrm{wt} \%, 15 \mathrm{wt} \%$ or $20 \mathrm{wt} \%)$.

Compression molding ( $3 \mathrm{MPa}$,

$160{ }^{\circ} \mathrm{C}$ ) to thickness of $1.0 \pm$

$0.1 \mathrm{~mm}$. Conduction of carbon

coating on both BPP sides.

Polyvinylidene fluoride (PVDF FR 904, 3F-Wanhao Fluorine

Chemical Co., Ltd.), dimethyl sulfoxide (DMSO AR, Beijing Modern Oriental Fine

Chemistry Co., Ltd.)

Polyethylene (Sinopec Shell, HDPE, 5121B)

Phenolic resin powder (Jiaxing Sicheng Chemical Co., Ltd.), boron carbide (Shanghai

Macklin Biochemical Co., Ltd.), silicon dioxide (Shanghai Rhawn Chemical Technology Co., Ltd.) (1.0:0.5:0.5:0.1)
Mixing of PVDF and DMSO

(3:16), heating and stirring $\left(80^{\circ}\right.$

C, 5 h). Soaking carbon felt into binder solution. Removing

DMSO $\left(80^{\circ} \mathrm{C}, 8 \mathrm{~h}\right)$.

Compression molding $\left(175{ }^{\circ} \mathrm{C}\right)$

to thickness of $0.75 \mathrm{~mm}$.

Surface modification via plasma treatment $(700 \mathrm{~W}, 5 \sim 10 \mathrm{~min}$, atmosphere) or coating with

flaked graphite or carbon nano tubes.

Preparation of polyethylene sheet (thickness $1 \mathrm{~mm}$ ) in mold (no pressure, $240{ }^{\circ} \mathrm{C}, 90 \mathrm{~s}$;

$80 \mathrm{~kg} \mathrm{~cm}^{-2}, 240{ }^{\circ} \mathrm{C}, 3 \mathrm{~min}$

water cooling $2 \mathrm{~min}$ ).

Preparation of BPP in mold:

Insert polyethylene sheet and carbon felt in mold (no pressure, $260{ }^{\circ} \mathrm{C}, 120 \mathrm{~s} ; 20 \mathrm{~kg} \mathrm{~cm}^{-2}$, $260^{\circ} \mathrm{C}, 3 \mathrm{~min}$; water cooling $2 \mathrm{~min}$ ).

Conductive binder: Mixing Phenolic resin, graphite powder, boron carbide and silicon dioxide with ethylene glycol.

Conductive binder coated on graphite plate with doctor blade method and graphite felt pressed on coating. Heat-treating
BPP with low carbon content

BPP with low carbon conten ( $\sim 70 \mathrm{wt} \%$ PVDF, $\sim 30 \mathrm{wt} \%$ carbon)

BPP-electrode assemblies 


\section{Table I. (Continued).}

No.

Literature

Conductive compound

Binder material and curing agen

Fabrication method

vacuum, different temperature

$\left.\left(600{ }^{\circ} \mathrm{C}, 800{ }^{\circ} \mathrm{C}, 1000{ }^{\circ} \mathrm{C}\right), 1 \mathrm{~h}\right)$

Polyvinylidene fluoride (PVDF)

(Shandong Huaxia Shenzhou

New Material Co. Ltd.)

phite powder (Qiangdao Herit

Graphite Products Co. Ltd.),

cactus-like carbon nanofibers

Spreading cactus-like carbon
Mixing polyvinylidene fluoride,

graphite and expanded graphite

(4:3:3), hot compression

molding $\left(5.5 \mathrm{MPa}, 180^{\circ} \mathrm{C}\right)$.

nanofibers on surface, hot com-

pression molding (1.0 MPa, 140

${ }^{\circ} \mathrm{C}, 2 \mathrm{~min}$ ).
Remark

Synthesis method of cactus-like carbon nanofibers is described in paper 
with high electrical conductivity or with properties of increasing flowability of the composite matrix are added in small amounts usually up to $4 \mathrm{wt} \%$. The remaining percentage is filled with insulating polymer as binder matrix. ${ }^{19,20,30,33} \mathrm{An}$ appropriate selection and composition between the single components of the composite material is important. Id est, conductive carbon black particles, for example, can only be introduced within amorphous polymer structures since the crystalline lattice of polymers has a repulsive effect on the carbon blacks. For instance, polypropyleneelastomer with integrated vinyl-monomers is an amorphous polymer. By adding a small amount of crystalline polymer to the amorphous polymer, the carbon black particles are ordered between the crystalline polymer structure and can form conductive paths within the composite material with an efficient amount of carbon black. $^{30}$

Usually the electrical conductivity of the BPP is dependent on different factors such as the quality, amount and mixture of conductive particles and their connectivity within the network of the composite matrix. On the one hand, Zhang et al. ${ }^{30}$ have shown that by adding conductive fillers such as carbon black and carbon fibers to a non-conductive polymer matrix, the volume conductivity is increased with respect to the conductive filler amount. In this context, carbon black provides better conductivity properties than carbon fiber by comparison of the same filler content above $10 \mathrm{wt} \% .{ }^{30}$ On the other hand, Haddadi et al. ${ }^{16}$ showed a non-linear relationship between the carbon black content within a carbon blackpolymer composite plate and the electrical conductivity of the BPP. The composite material with a carbon black content of up to $5 \mathrm{wt} \%$ has a very high resistivity comparable with pure polymer. The electrical conductivity increases rapidly between $5 \mathrm{wt} \%$ and $25 \mathrm{wt} \%$ carbon black and shows no significant additional rise at higher amounts. However, by replacing a certain percentage of the carbon black against graphite fibers the conductivity can be increased due to better connection between the conductive particles. ${ }^{16}$ In a graphite/ carbon black mixed polymer composite plate, an optimum content of $15 \mathrm{wt} \%$ carbon black leads to a compact structure with good electrical conductivity and electrochemical stability. Lower and higher carbon black contents reduce the electrical conductivity due to pore development or formation of carbon black aggregates. ${ }^{17,45}$ Correspondingly, carbon nanotubes in a graphite-polymer composite BPPs improve the electrical conductivity due to bridging gaps between graphite particles. ${ }^{19,29}$ Some working groups recently focus on increasing the percentage of binder material in order to reach a high flexural strength of the BPPs by maintaining a high electrical conductivity. Thus, e.g. BPPs with carbon contents of up to $30 \mathrm{wt} \%$ only are developed. In one case, the good electrical conductivity is preserved by using a sufficient amount of a mixture of different carbon components which ensure the development of a continuous conductive network within the binder material. ${ }^{49}$ In another case the electrical conductivity is provided by a carbon felt with a good fiber connectivity which is soaked with PVDF or injection molded with polyethylene. ${ }^{50}$ Liao et al. ${ }^{31}$ have even developed a BPP with a very low content of carbon (graphite powder, graphene and carbon fibers) between $9.4 \mathrm{wt} \%$ and $18.7 \mathrm{wt} \%$ and epoxy thermosetting resin as binder. Despite the low content of conductive material the composite BPP showed high electrical conductivity due to a sufficient connective carbon network between the single particles and a good operation performance within a VRFB single cell. ${ }^{31}$

Fabrication.-The amounts of conductive filler and polymer have an influence on the composite material processability and mechanical strength of the BPPs. For example, Park et al. were mixing different conductive fillers with epoxy resin and found that compression molded BPPs were rather fragile and brittle when the total conductive filler content exceeded $90 \mathrm{wt} \%$. On the contrary, when the total filler content was lower than $60 \mathrm{wt} \%$, the plates were not easy to be produced since the viscosity of the composite material was too high. ${ }^{20}$ In another study, a monoalkoxy titanate-based coupling agent was added to a polyphenylene sulfide and conductive filler mixture in order to achieve a better flow behavior of the composite material during the manufacturing process resulting in an optimized filler dispersion and electrical conductivity. ${ }^{19}$

There is a variety of procedures for composite preparation and production of BPPs. The following description gives an overview about general manufacturing of composite BPPs by compression and injection molding, but does not cover single specific production approaches applied by different research groups (e.g. plate extrusion or foil extrusion). During the molding step it is important to ensure proper and uniform distribution of graphite particles within the polymer binder material in order to attain the electrical conductivity of the completed plates. ${ }^{33}$ Therefore, the raw graphite and polymer particles first have to be linked by mixing the carbon filler and binder material and then they are compounded in a twin screw extruder in order to obtain composite material that is cut into granulates with diameters of e.g. $4 \mathrm{~mm} .{ }^{33,54}$ A proper mixing time during this procedure is crucial to obtain an accurate dispersion of the conductive particles resulting in improved conductivity. However, stirring the composite material for a too long period can result in breakage of graphite particles with increasing resistivity. ${ }^{16}$ The mixed granulates are then introduced into a compression or injection molding device to form the BPPs (Fig. 3). For compression molding the granulates are filled and smoothed in the open molding form. Then the filling is compressed in the heated mold with a hydraulic piston using a high clamping force. The curing time determines the cycle time for the production of one BPP from preheating step to removal of the plate. The manual manufacturing of BPPs through compression molding requires labor force which makes the method more cost intensive than injection molding that runs semi- or fully-automated. Injection molding devices use a rotating screw within a heated barrel. Thus, the exerted heat and shear forces soften the introduced granulates that are subsequently injected into the mold. The BPP can be removed after maintaining the curing time of the material. ${ }^{18,33,55}$ In general, a thin insolating polymer film develops during the injection and compression a)

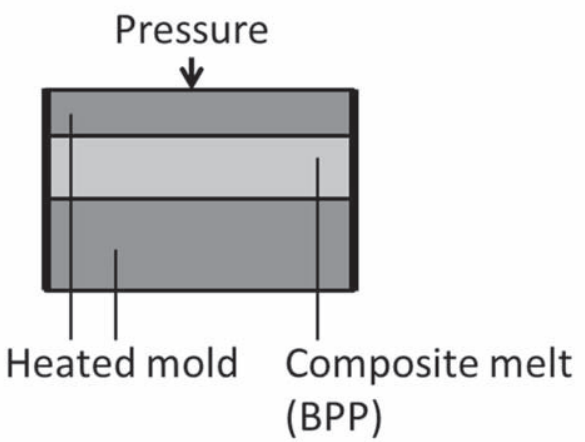

b)

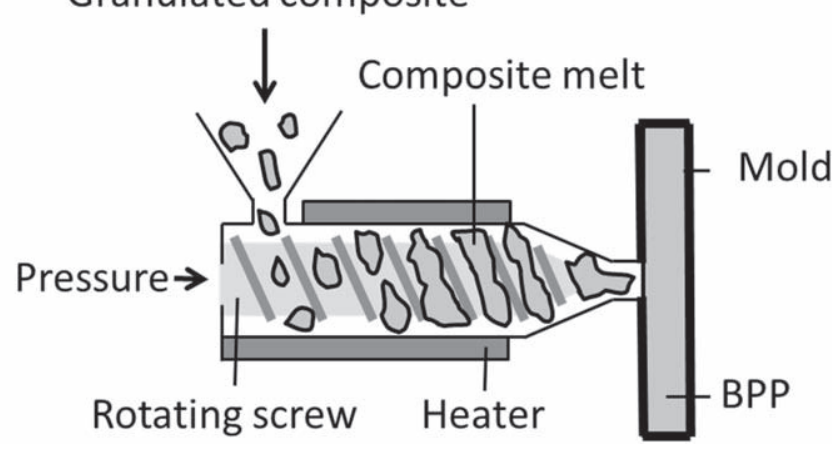

Figure 3. Schematic overview of BPP production via a) compression molding and b) injection molding.[18, 55.] 
molding procedure. Since the BPPs need good electrical contact conductivity, the thin polymer film has to be removed by grinding, sandblasting or an excess resin-absorbing method using a polyester fabric. As an alternative to remove the polymer layer, conductive carbon fibers, carbon nanotubes (CNT) or an expanded graphite coating can be attached to the surface. ${ }^{15,26,29,33,36,41,50,48}$ An overview of the compositions and manufacturing processes of a variety of carbon based composite BPPs for the VRFB is shown in Table I.

Design.-There are different composite BPP designs with or without flow fields which are used in VRFBs (Fig. 4). In the first case, parallel flow channels are integrated in the BPP geometry (Fig. 4a). The channels are located adjacent to the electrode felts and are open at both ends. This design results in a flow-by cell with low pressure drops. However, due to the channel configuration of the BPPs, the electrolyte flow is not forced through the electrodes and thus results in rather low cell performance. Besides the parallel flow field design, the channels can also be arranged as serpentines (Fig. 4b) which still lead to lower pressure drops than in the third case where the BPPs are even and contain no flow channels (Fig. 4c). The flat BPP design leads to a flowthrough configuration of the VRFB cell. The electrolyte is forced to flow next to the even BPP and thus the reactive vanadium species are transported directly through the porous electrode matrix. However, this configuration requires thicker electrodes than used in the flow-by design, in order to decrease the pressure drop in cells with large dimensions. A setup with thicker electrodes, however, may lead to higher diffusion and ohmic losses. The flow-by and flow-through configuration can be combined to an interdigitated flow field when the alternating inlet and outlet channels of the BPP are blocked (Fig. 4d). Due to the blockage the electrolyte is forced to flow through the porous electrode between adjacent parallel channels. In this configuration low pressure drops are obtained and the cell reaches high performance even with rather thin electrodes. ${ }^{3,6,11,56,57}$ Further flow field geometries in BPPs for redox flow batteries, such as the spiral or the mesh design, are also mentioned in literature. ${ }^{5,59}$ However, not only the arrangement of flow fields, but also the channel and land width or the channel depth and length have an impact on the pressure drop and the overpotential loss. ${ }^{60}$

BPPs with integrated flow fields are commonly applied and investigated-at least in laboratory experiments or numerical models - in order to support a homogeneous distribution of electrolytes and thus a better battery performance. ${ }^{61}$ However, upscaling of VRFB in size might change the electrolyte flow conditions through the half-cells leading to limitations of homogeneous electrolyte distribution, polarization effects or higher pressure drops. Thus, these effects need to be investigated quantitatively and appropriate flow field configurations need to be adapted or developed. ${ }^{2}$ An optimal geometry of flow channels needs to be a reasonable compromise which fulfills low pressure drops and reduces shunt currents within flow battery stacks at the same time. ${ }^{63}$ For large scale applications the hierarchical interdigitated flow field might be a promising option which reduces pumping losses compared to the interdigitated flow field. ${ }^{64}$ Nevertheless, sharp edges and corners of the flow field geometry provide disadvantageous conditions regarding corrosion of the BPP through the oxidizing properties of the electrolytes. Thus, a new approach is to switch to independent flow field components that are not integrated within the BPP, but are inserted separately between the membrane and the electrode. ${ }^{61}$

The above paragraph describes literature findings which are usually lab-scale based. However, it is questionable, if flow fields in BPPs are also commonly used in real VRFB applications. Since there is no literature available about this topic, one-to-one interviews were carried out with well-known VRFB stack manufacturers and BPP producers. The statements in these conversations were rather consistent and complementary. All of the interviewed companies provide or apply flat BPPs for/in VRFB stacks. At the time of first stack design the cost, durability and reduction of complexity of the battery system were usually the most important factors leading to the choice of flat BPPs. Most stack manufacturers stick with flat BPPs as reliable stack components - apart from some conducted scientific projects where BPPs with flow fields were tested. Implementation of flow fields to the BPPs would either positively or negatively affect other relevant process parameters, such as ohmic resistance, electrolyte pressure drop, mechanical stability of the BPP, leak tightness of the stack, electrolyte flow properties through the half-cells, etc. In addition, BPPs with flow fields offer a larger surface area with less interfacial contact area to the felt electrode with more probability for oxidation and material erosion due to corrosion effects. Flat BPPs can usually be produced less timeconsuming and more cost efficient. Thus, they are economically more attractive for the stack manufacturers. There are also BPPs on the market which are too thin to enable the introduction of a flow field or the material composition and/or production method are not suitable to allow an additional structuring. Although flow fields might offer some advantages to the battery system, some stack manufacturers just doubt the cost-benefit ratio for application of structured BPPs (one-to-one interviews were performed with Enerox GmbH, J. Schmalz GmbH, VANEVO GmbH, Volterion GmbH \& Co. KG, VoltStorage GmbH, Eisenhuth $\mathrm{GmbH} \& \mathrm{Co}$. KG, SGL CARBON GmbH). However, it is a) Parallel flow field b) Serpentine flow field Flow-by cell
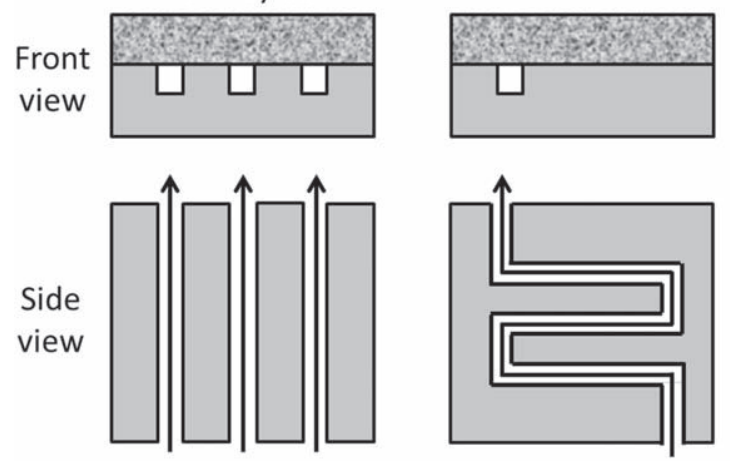

d) Interdigitated flow field
Bypass flow-through cell

Flow-through cell
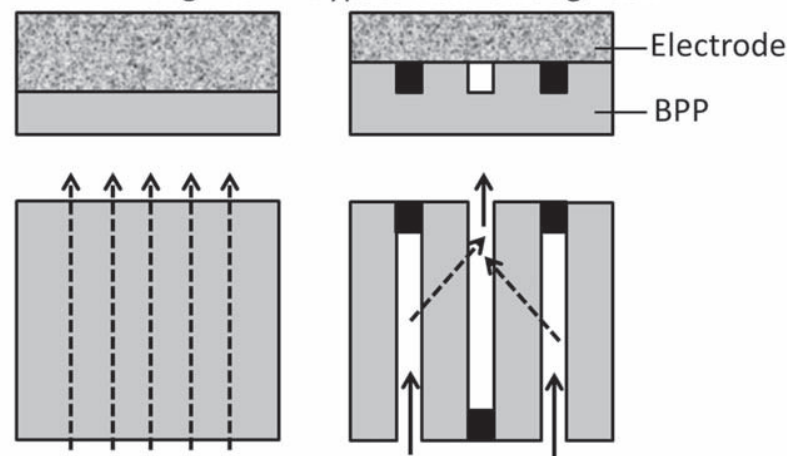

Figure 4. Schematic overview of different BPP geometries and electrolyte flow configurations in cross-sections of front (outlet) and side view with ribs in grey, flow channels in white and blockages in black. Continuous arrows show electrolyte flow mainly through channels, dashed arrows show electrolyte flow through felt electrodes. (a) Parallel BPP flow field resulting in electrolyte flow-by cell configuration. (b) Serpentine BPP flow field. (c) No BPP flow field resulting in electrolyte flow-through cell configuration. (d) Interdigitated BPP flow field resulting in an electrolyte bypass flow-through cell configuration. Thicknesses of electrodes, BPPs and channels are not to scale. Schematic modified from sources. ${ }^{3,56,57}$ 
not excluded that their approach might change in the future. Therefore, scientific research within this area is still relevant and ongoing.

\section{Connection and Combination of Electrodes and Bipolar Plates}

Usually the carbon-polymer based composite BPPs are pressedcontacted to electrode felts within the stack in order to enable a conductive connection between both components (Fig. 5a). ${ }^{14,17,29,30}$ The higher the compression pressure the lower the contact resistance. However, by applying more compression force, the graphite felts are compressed resulting in lower porosity and higher electrolyte flow resistance through the cell. ${ }^{45,47}$ Thus, the applied compression force has to be optimized in order to achieve a good cell efficiency.

In addition, there are approaches for development of united fabrics that fulfill the properties and function of combined electrodes and BPPs. These approaches are either based on two heat-bonded electrode felts via a polymer layer (Fig. 5b) or fused BPP-electrode assemblies (Fig. 5c)., 2,45,47

The fusion of two electrode felts was obtained by different approaches (Fig. 5b). In one case two electrode felts were heat bonded by a non-conductive adhesive polymer layer. The connection of fibers from opposite graphite felts within the polymer matrix enabled the electrical conductivity of the obtained unit. ${ }^{23}$ In another case two electrodes were connected by heat-bonding through an adhesive polymer layer containing carbon black as filler material within the polymer matrix. However, the content of carbon black in the polymer layer led to low melt flow during production and resulted in bad electrical conductivities. In addition, carbon black is susceptible to degradation and can lead to leakage paths during operation. $^{4,16,23}$

BPP-electrode assemblies can be obtained by fusion of a BPP with felt electrodes on both sides (Fig. 5c). In one case an adhesive layer consisting of thermo-plastic phenol formaldehyde resin and hexamethylene tetramine mixed with graphite powder and carbon black as conducting particles was used to heat bond a graphite felt to a flexible graphite BPP. The layer reduced the area resistance between both components. ${ }^{47}$ In another case first a BPP was prepared by a curing process between a carbon fabric and a polyethylene powder/carbon black mixture which was then heat bonded to felt electrodes on each side. It was shown that the area specific resistance of the assembly was lower compared to a conventional graphite BPP. ${ }^{45}$ Again in another case a graphite felt was heat bonded to a graphite BPP by applying a conductive binder containing phenolic resin, boron carbide, silicon dioxide and graphite powder. This assembly had good electrical conductivities and showed higher efficiencies during battery operation in comparison to the felt and BPP without the conductive binder. ${ }^{51}$
Characterization.-This chapter attempts to provide a literature overview of important characteristics of BPPs which are especially their electrical conductivity, their mechanical strength, their impermeability and their efficiency during battery operation. However, it is a challenge to compare the properties of BPPs from literature one-to-one since varieties of different methods, equipment and sample sizes are applied during the measurements. That means, there is no standard procedure available for the single characterization methods. Furthermore, in many publications the experimental procedures are not described in detail. Despite these circumstances and uncertainties, the following tables list experimental conditions and measured properties of different BPPs in order to enable a critical consideration of the BPPs' properties. However, the following tables do not raise the claim to provide all available information since the values are often presented in terms of graphs comparing a variety of BPP materials. Thus, in some cases the experimental results within the tables are reduced to the most relevant ones from the subjective perspective of the review's author and to values that were highlighted by the cited authors within their papers. For further and more detailed information the author of this review is referring to the according cited literature.

Electrical conductivity.-The electrical conductivity of BPPs is an essential property for a good performance of VRFB stacks. The in-plane and through-plane electrical resistivity values of different BPPs are presented in Table II and Table III. It should be noted that the values from literature, including the electrical conductivity, were recalculated to $\mathrm{m} \Omega \cdot \mathrm{cm}$ and $\mathrm{m} \Omega \cdot \mathrm{cm}^{2}$ for comparison reasons. The inplane resistivity is usually measured with the four point probe technique. In order to correctly calculate the in-plane resistivity, it is necessary to take into account correction factors that are e.g. dependent on the geometry and thickness of the sample and the probe spacing. ${ }^{65-67}$ However, in most cases these parameters are not mentioned in the publications (Table II) and it is not clear, how the conductivities/resistivities were calculated. Nevertheless, one of the lowest in-plane electrical resistivity of $2.38 \mathrm{~m} \Omega \cdot \mathrm{cm}$ was recorded with a BPP that contains conductive carbon compounds at only a low load of $25 \mathrm{wt} \%$. $^{49}$

The through-plane electrical resistivity is usually measured by compressing the BPP between two stamps and conducting a fixed current while measuring the voltage drop. The obtained resistivity values are mainly dependent on the applied compression pressure and on additional conductive compounds (such as carbon papers) in between the stamps and the BPP in order to reduce the contact resistance as well as the used calculation method. ${ }^{26,50,51}$ For comparison reasons, it would be therefore necessary to choose the same compression pressure. However, the literature review has shown that e.g. the applied compression pressure and the chosen
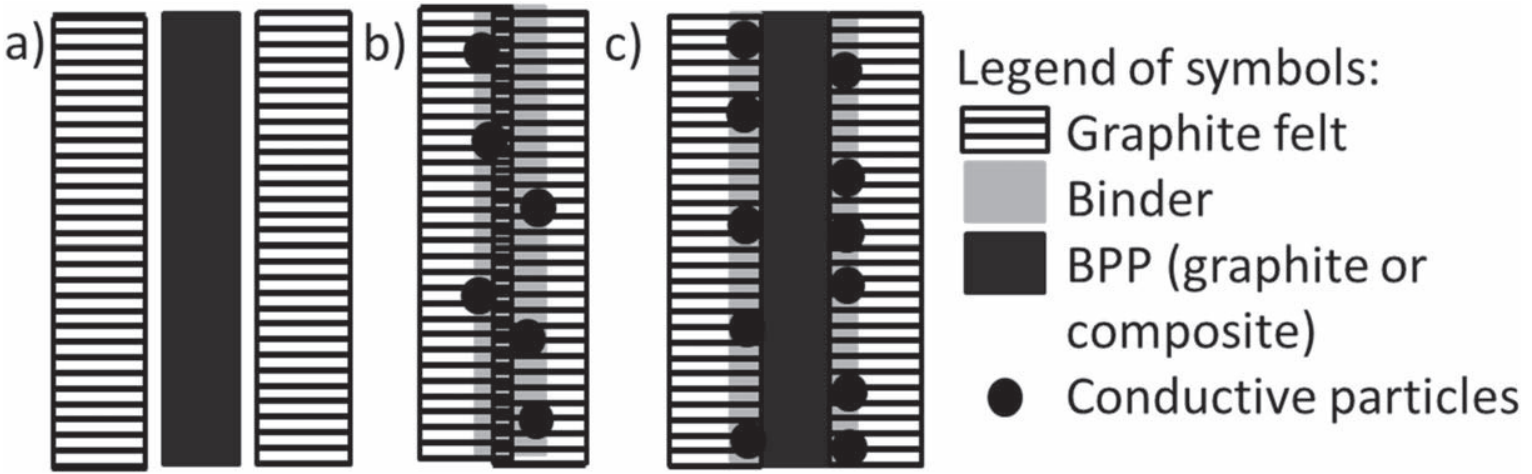

Figure 5. Connection and combination of electrodes and BPPs. (a) Two graphite felts are pressed-contacted to a conductive graphite or carbon-polymer based composite BPP by compression force. (b) Two electrodes heat-bonded via an adhesive polymer layer with or without conductive particles integrated within the binder. (c) Heat-bonded graphite BPP-electrode assembly, e.g. by using an adhesive conductive polymer layer. Schematics modified from sources. ${ }^{23,47}$ 


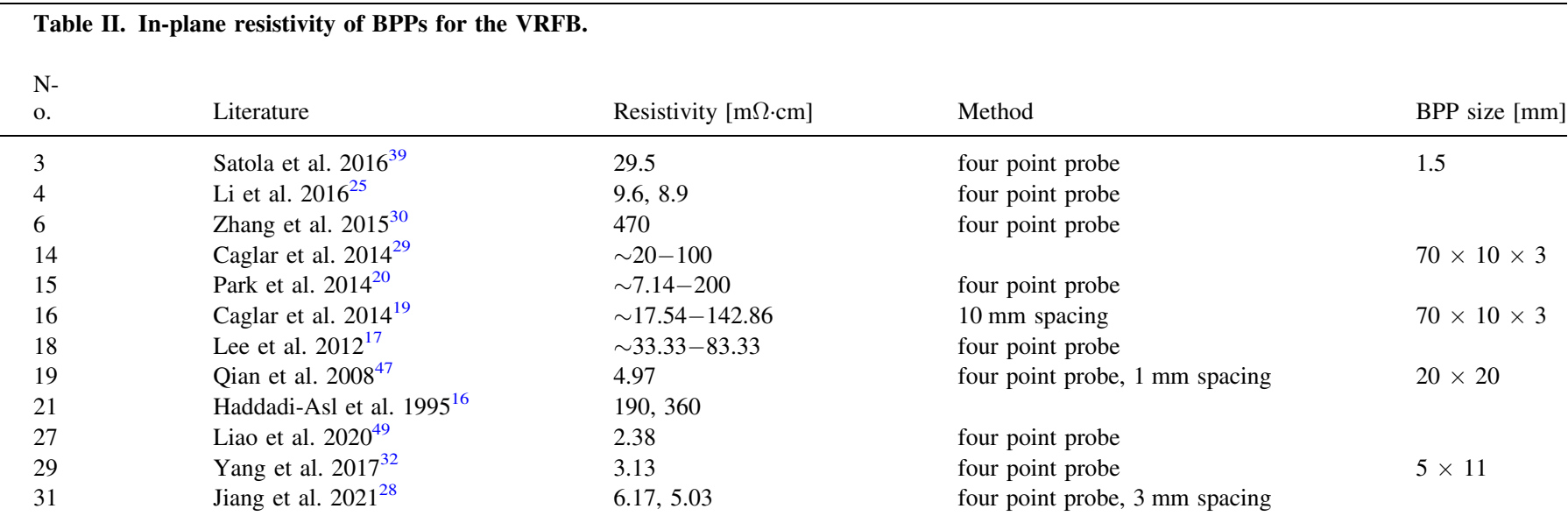

BPP size vary which results in large differences between the measured values (Table III). Most frequently a pressure of $0.05 \mathrm{MPa}$ is used and a BPP size of $100 \mathrm{~mm} \times 100 \mathrm{~mm}$ with different thicknesses is preferred. In addition, gold coated stamps and an applied current of $1 \mathrm{~A}$ are favored. The lowest recorded area specific resistances between $3.3-5 \mathrm{~m} \Omega \cdot \mathrm{cm}^{2}$ are recorded at varying or insufficiently specified conditions. ${ }^{31,33,49,51}$

Impermeability. - The BPPs need to be impermeable for vanadium electrolyte in order to physically separate the positive and negative electrolyte solutions of adjacent cells within a stack. Usually impermeability tests are performed by inserting a BPP between two chambers filled with gases or liquids, such as the vanadium electrolyte, and by applying gas/air pressure for a certain time. The crossover of gas or ions from the first to the second chamber is measured. Despite the fact that a variety of different gas or fluid media, test pressures and durations were described in literature, in most cases the tested BPPs are generally impermeable (Table IV). Therefore, carbon-polymer composites are considered to be reliable impermeable materials for BPPs.

Mechanical properties.-BPPs are exposed to different forces within the stack since the VRFB is compressed in order to provide an impervious system and to decrease the contact resistance between the carbon felts and BPPs. Therefore, BPPs generally need to resist compressive and bending forces. In different publications the mechanical properties of BPPs are usually characterized by measuring their flexural, compressive and/or tensile strength at varying test speed and on BPPs with diverse dimensions (Table V). However, it is questionable, if the measurement of the tensile strength is a meaningful parameter since the BPP is not faced with tensile forces in the stack. One of the highest values are found to be $471 \mathrm{MPa}$ for tensile strength, ${ }^{48} \sim 275 \mathrm{MPa}$ for flexural strength $^{41}$ and $76 \mathrm{MPa}$ for compressive strength. ${ }^{33}$ The elongation of BPPs with no break was reached up to $>400 \%$. $^{23}$

Efficiency.-Another essential parameter of BPPs is their overall performance during battery operation. The general performance of VRFB stacks is characterized by the voltage, coulombic and energy efficiency. The coulombic efficiency decreases due to crossover effects and side reactions. The voltage efficiency is influenced by the ionic conductivity of the membrane, bulk and contact resistances of electrodes and BPPs, the operation current density, the electrolyte flow rate and mass transport. And the energy efficiency is a product between the coulombic and voltage efficiency. ${ }^{47,68}$ Therefore, the efficiency values are dependent on different factors and describe not solely the properties of the BPPs but of the whole battery system. A comparable investigation of the BPP's performance would be only approximately possible by keeping the battery system constant (including the components and electrolyte solutions as well as the operation parameters) while exchanging only the BPP samples. And here, again, it is a challenge or rather impossible to compare the BPP performances within VRFB stacks of different examples from literature by taking into account only the efficiency values. There are too many varying or unmentioned battery system parameters that influence the overall voltage, coulombic and energy efficiencies. Thus, the efficiencies can only be regarded separately within each single paper by considering the overall battery conditions and cannot stand for the approximate performance of the BPPs. Nevertheless, for completeness, the efficiency values of the literature review are listed in Table VI.

\section{Aging of Carbon Based Bipolar Plates}

BPPs are in direct contact to the acidic and highly corrosive vanadium electrolyte. ${ }^{10,11}$ In order to secure the long-term durability of VRFBs, it is therefore necessary to carefully select appropriate materials for BPPs and ensure conditions that reduce the possibility of aging or alteration. ${ }^{27}$ This chapter concentrates on the theoretical background of carbon and composite BPP corrosion within vanadium electrolyte or VRFBs and provides available praxis examples of aging experiments from literature. It is necessary to mention that the corrosion measurements are usually performed on the composite BPPs, while the (electro)chemical stability of the single components, e.g. the binder, is not analyzed separately. This approach is reasonable since the composite material might have other properties than the individual constituents. In general, non-conductive polymers have a good electrochemical stability and the chemical stability of e.g. some rubbers, resins (epoxy, phenolic) and PVDF in composite BPPs is indicated but usually not experimentally investigated. ${ }^{16,17,25,50,61}$

Electrochemical corrosion-theoretical background.-The potential between the BPPs and the electrolyte is considered to be the main cause for electrochemical corrosion of composite BPPs. ${ }^{14}$ Carbon degradation can develop, if the polarized potential on the BPP is more positive than that of the oxygen evolution reaction. ${ }^{69}$ The corrosion of graphite (electrodes) in vanadium electrolyte was investigated during polarization at different potentials from 1.5 $-2.0 \mathrm{~V}$ while the evolving gas was analyzed by means of on-line mass spectrometry. ${ }^{70}$ The oxidation of graphite probably takes place via a corrosion progression from $\mathrm{C}-\mathrm{H}, \mathrm{C}-\mathrm{OH}, \mathrm{C}=\mathrm{O}$ and $\mathrm{COOH}$ to the evolution of $\mathrm{CO}$ or $\mathrm{CO}_{2}$ and the loss of carbon material. ${ }^{30,40}$ The evolution of $\mathrm{CO}_{2}$ and $\mathrm{CO}$ gas is more enhanced than $\mathrm{O}_{2}$ development at lower potentials, while $\mathrm{O}_{2}$ is the main gas component at higher polarization potentials. ${ }^{70}$ It was shown that the corrosion in the positive half-cell electrolyte is less pronounced in the presence of $\mathrm{VO}^{2+}$ or at low state of charge (SOC), respectively, since the oxidation of graphite is hindered by the oxidation of vanadium ions. $^{5,70}$ In addition, at high SOC the environment of the fully charged positive half-cell electrolyte containing oxidizing $\mathrm{VO}_{2}{ }^{+}$ 


\begin{tabular}{|c|c|c|c|c|c|c|c|}
\hline No. & Literature & Area specific resistance $\left[\mathrm{m} \Omega \cdot \mathrm{cm}^{2}\right]$ & Resistivity $[\mathrm{m} \Omega \cdot \mathrm{cm}]$ & Stamps & Current $[\mathrm{A}]$ & Pressure[MPa] & BPP size $[\mathrm{mm}]$ \\
\hline 1 & Nam et al. $2017^{15}$ & $143-156$ & & gold coated & 1 & 0.05 & $100 \times 100 \times 0.24$ \\
\hline 2 & Lee et al. $2017^{36}$ & $\sim 18-38$ & & gold coated & 1 & 1.38 & $100 \times 100$ \\
\hline \multirow[t]{2}{*}{3} & Minke et al. $2016^{33}$ & 12 & & & & 1 & \\
\hline & & & 55 & & & 6.9 & 2 \\
\hline 7 & Lee et al. $2015^{41}$ & 18 & & & 1 & 1.38 & $100 \times 100 \times 0.25$ \\
\hline \multirow[t]{3}{*}{10} & Lim \& Lee $2015^{45}$ & $\sim 500$ & & gold coated & & 0.05 & $100 \times 100 \times 0.4$ \\
\hline & & $200^{\mathrm{a})}$ & & gold coated & & 0.05 & $100 \times 100 \times 0.4$ \\
\hline & & 305 & & gold coated & & 1.2 & $100 \times 100 \times 0.4$ \\
\hline 11 & Choe et al. $2015^{26}$ & $\sim 100-120$ & & gold coated & 1 & $0.05(0.01-0.10)$ & $100 \times 100 \times$ different thickness \\
\hline 13 & Kim et al. $2014^{14}$ & $\sim 130-148$ & & & & 0.05 & $100 \times 100 \times 0.41$ \\
\hline 14 & Caglar et al. $2014^{29}$ & & $\sim 100-500$ & gold coated & & 1 & $10 \times 10 \times 3$ \\
\hline 15 & Park et al. $2014^{20}$ & & $\sim 18-200$ & copper & & & \\
\hline 16 & Haddadi-Asl et al. $1995^{19}$ & & $\sim 50-667$ & gold coated & & 1 & $10 \times 10 \times 3$ \\
\hline 19 & Qian et al. $2008^{47}$ & $\sim 70-190^{\text {a) }}$ & & talmigold & & $0.05-0.70$ & $2000 \mathrm{~mm}^{2}$ \\
\hline 20 & Hagg \& Skyllas-Kazacos $2002^{23}$ & $600-18000^{\mathrm{a})}$ & & copper & & 0.02 & \\
\hline \multirow[t]{2}{*}{23} & Minke et al. $2016^{33}$ & 11 & & & & 1 & \\
\hline & & & 50 & & & 6.9 & 2 \\
\hline \multirow[t]{2}{*}{24} & Minke et al. $2016^{33}$ & 5 & & & & 1 & \\
\hline & & & 24 & & & 6.9 & 2 \\
\hline 25 & Liao et al. $2019^{31}$ & $3.3-40.3$ & & gold coated & 1 & & $120 \times 100 \times 1.4$ \\
\hline 26 & Lee et al. $2018^{48}$ & 210 & & & & $0.05(0.01-0.1)$ & $100 \times 100 \times 0.2$ \\
\hline 27 & Liao et al. $2020^{49}$ & 5 & & gold coated & 1 & & $120 \times 100 \times 1$ \\
\hline 28 & Liu et al. $2018^{50}$ & $\sim 125-165$ & & & & $0.09(0.015-0.09)$ & \\
\hline 30 & Dongjiang et al. $2020^{51}$ & $\sim 3.4$ & & gold coated & & $0.05(0.05-0.175)$ & $50 \varnothing$ circle, 2 (BPP) and 5 (felt) thickness \\
\hline 31 & Jiang et al. $2021^{28}$ & $37.7,25.4$ & & copper & 1 & & $120 \times 100 \times 1$ \\
\hline
\end{tabular}

a) BPP-felt assembly. 
Table IV. Impermeability measurement method and results of BPPs for the VRFB.

\begin{tabular}{|c|c|c|c|c|c|c|}
\hline No. & Literature & (Im)permeability & Medium & Pressure $[\mathrm{MPa}]$ & BPP size $[\mathrm{mm}]$ & Duration $[\mathrm{h}]$ \\
\hline 1 & Nam et al. $2017^{15}$ & impermeable & air & 0.2 & & 100 \\
\hline 2 & Lee et al. $2017^{36}$ & impermeable & air & 0.3 & & 100 \\
\hline 4 & Li et al. $2016^{25}$ & $3 \times 10^{-7} \mathrm{~cm}^{3} \mathrm{~cm}^{-2} \mathrm{~s}^{-1}$ & hydrogen & 0.2 & $50 \times 50$ & 2 \\
\hline 7 & Lee et al. $2015^{41}$ & impermeable & air & 0.3 & $40 \varnothing$ & 100 \\
\hline 10 & Lim \& Lee $2015^{45}$ & impermeable & air & 0.3 & $30 \varnothing$ & 100 \\
\hline 19 & Qian et al. $2008^{47}$ & impermeable & chamber 1: $1.5 \mathrm{M} \mathrm{VO}^{2+}$ in $3 \mathrm{M} \mathrm{H}_{2} \mathrm{SO}_{4}$, chamber 2: distilled water, with pumping & & & 500 \\
\hline 20 & $\begin{array}{l}\text { Hagg \& Skyllas- } \\
\text { Kazacos } 2002^{23}\end{array}$ & impermeable & $\begin{array}{l}\text { chamber 1: } 2 \mathrm{M} \mathrm{V}^{3.5+} \text { in } 2 \mathrm{M} \mathrm{H}_{2} \mathrm{SO}_{4} \text {, chamber 2: } 2 \mathrm{M} \mathrm{H}_{2} \mathrm{SO}_{4} \text {, with and without } \\
\text { pumping }\end{array}$ & & & 2 months \\
\hline 25 & Liao et al. $2019^{31}$ & impermeable & chamber 1: $1.5 \mathrm{M} \mathrm{VOSO}_{4}$ in $3 \mathrm{M} \mathrm{H}_{2} \mathrm{SO}_{4}$, chamber 2: $3 \mathrm{M} \mathrm{H}_{2} \mathrm{SO}_{4}$ & 0.1 & & $30 \mathrm{~d}$ \\
\hline 26 & Lee et al. $2018^{48}$ & impermeable & air & 0.1 & & 100 \\
\hline 27 & Liao et al. $2020^{49}$ & impermeable & $1.5 \mathrm{M} \mathrm{VOSO}_{4}$ in $3 \mathrm{M} \mathrm{H}_{2} \mathrm{SO}_{4}$ & 0.1 & & 1 month \\
\hline 28 & Liu et al. $2018^{50}$ & impermeable & electrolyte & & & 72 \\
\hline
\end{tabular}




\begin{tabular}{|c|c|c|c|c|c|c|c|c|}
\hline No. & Literature & Tensile strength [MPa] & Flexural strength $[\mathrm{MPa}]$ & Compressive strength $[\mathrm{MPa}]$ & Elongation (at break) [\%] & $\mathrm{T}\left[{ }^{\circ} \mathrm{C}\right]$ & BPP size $[\mathrm{mm}]$ & Test speed $[\mathrm{mm} / \mathrm{min}]$ \\
\hline 1 & Nam et al. $2017^{15}$ & $308-358$ & & & & 20 & $\begin{array}{l}100 \times 10 \times \\
0.24\end{array}$ & \\
\hline 2 & Lee et al. $2017^{36}$ & 79.3 & & & & 25 & $100 \times 15 \times 0.5$ & 1 \\
\hline 3 & Minke et al. $2016^{33}$ & & 40 & 50 & & & & \\
\hline 4 & Li et al. $2016^{25}$ & $31.9,64.9$ & & & & & $150 \times 20 \times 1$ & 10 \\
\hline & & & $62.3,33.2$ & & & & $120 \times 20 \times 1$ & 5 \\
\hline 5 & Liu et al. $2015^{40}$ & 14.8 & & & & & & \\
\hline 6 & Zhang et al. $2015^{30}$ & 6.6 & & & 250 & & & 200 \\
\hline 7 & Lee et al. $2015^{41}$ & 412 & & & & 25 & $\begin{array}{l}100 \times 100 \times \\
0.25\end{array}$ & \\
\hline & & & $\sim 275$ & & & & $\begin{array}{l}50.8 \times 12.7 \times \\
0.9\end{array}$ & \\
\hline 14 & Caglar et al. $2014^{29}$ & & $\sim 35-48$ & & & & $60 \times 10 \times 3$ & \\
\hline 15 & Park et al. $2014^{20}$ & & $\sim 8-29$ & $\sim 25-35$ & & & & \\
\hline 16 & Caglar et al. $2014^{19}$ & & $\sim 71-96$ & & & & $60 \times 10 \times 3$ & 2 \\
\hline 20 & $\begin{array}{l}\text { Hagg \& Skyllas- } \\
\text { Kazacos } 2002^{23}\end{array}$ & $8.2-26.0$ & & & $290 \rightarrow 400$ & & & \\
\hline 23 & Minke et al. $2016^{33}$ & & 40 & 60 & & & & \\
\hline 24 & Minke et al. $2016^{33}$ & & 40 & 76 & & & & \\
\hline 25 & Liao et al. $2019^{31}$ & & $35.2,48.1$ & & & & $30 \times 25 \times 1.4$ & 2 \\
\hline 26 & Lee et al. $2018^{48}$ & 471 & & & & 25 & $\begin{array}{l}100 \times 15 \times \\
0.24\end{array}$ & 2 \\
\hline 27 & Liao et al. $2020^{49}$ & & $19.6,28.4$ & & & & $30 \times 20 \times 1.0$ & 1 \\
\hline 29 & Yang et al. $2017^{32}$ & 18.56 & & & 16 & & & \\
\hline
\end{tabular}


Table VI. Energy (EE), voltage (VE) and coulombic (CE) efficiencies of VRFB charge/discharge measurements by applying different BPPs.

\begin{tabular}{|c|c|c|c|c|c|c|c|c|c|c|c|c|}
\hline No. & Literature & $\begin{array}{l}\mathrm{EE} \\
{[\%]}\end{array}$ & $\begin{array}{l}\mathrm{CE} \\
{[\%]}\end{array}$ & $\begin{array}{l}\mathrm{VE} \\
{[\%]}\end{array}$ & $\begin{array}{l}\text { Charge/discharge } \\
\text { voltage [V] }\end{array}$ & $\begin{array}{c}\text { Cell- } \\
\text { s }\end{array}$ & $\begin{array}{l}\text { Current density } \\
{\left[\mathrm{mA} / \mathrm{cm}^{2}\right]}\end{array}$ & $\begin{array}{c}\text { Active area } \\
{\left[\mathrm{cm}^{2}\right]}\end{array}$ & Electrolyte & $\begin{array}{l}\text { Electrolyte } \\
{[\mathrm{L}]}\end{array}$ & Cycles & $\mathrm{T}\left[{ }^{\circ} \mathrm{C}\right]$ \\
\hline \multirow[t]{3}{*}{1} & Nam et al. $2017^{15}$ & 84.3 & & & $1.2-1.6$ & 1 & 60 & $4900^{\mathrm{a})}$ & & 0.05 & 20 & \\
\hline & & 83.4 & & & $1.2-1.6$ & 1 & 80 & $4900^{\mathrm{a})}$ & & 0.05 & 20 & \\
\hline & & 80.4 & & & $1.2-1.6$ & 1 & 100 & $4900^{a)}$ & & 0.05 & 20 & \\
\hline \multirow[t]{2}{*}{6} & Zhang et al. $2015^{30}$ & 82 & 96 & 85 & & 1 & 70 & 28 & $1.5 \mathrm{M} \mathrm{V}^{\mathrm{n}+}$ and $2 \mathrm{M}$ sulphate & 0.1 & 112 & 25 \\
\hline & & 75 & 93 & 80 & & 5 & 50 & 2000 & & 16.5 & 2300 & \\
\hline \multirow[t]{2}{*}{9} & Choe et al. $2016^{44}$ & $\sim 82$ & & & $1.2-1.6$ & 1 & 100 & & $1.6 \mathrm{M}$ vanadium ion & 0.05 & & \\
\hline & & $\sim 71$ & & & $1.0-1.7$ & 1 & 200 & & $1.6 \mathrm{M}$ vanadium ion & 0.05 & & \\
\hline 10 & Lim \& Lee $2015^{45}$ & 84 & $\sim 96$ & $\sim 98$ & & 1 & & & & & 100 & \\
\hline 11 & Choe et al. $2015^{26}$ & 80 & & & & & & & & & & \\
\hline 13 & Kim et al. $2014^{14}$ & 86 & $\sim 94$ & $\sim 92$ & $1.2-1.6$ & 1 & 100 & $6400^{\mathrm{a})}$ & & 0.05 & & \\
\hline \multirow[t]{3}{*}{14} & Caglar et al. $2014^{29}$ & $\sim 85$ & & & $0.8-1.6$ & 1 & 25 & 40 & & & & \\
\hline & & $\sim 77$ & & & $0.8-1.6$ & 1 & 50 & 40 & & & & \\
\hline & & $\sim 65$ & & & $0.8-1.6$ & 1 & 75 & 40 & & & & \\
\hline \multirow[t]{4}{*}{15} & Park et al. $2014^{20}$ & $\sim 85$ & $\sim 97$ & & $0.8-1.65$ & 1 & 40 & 5 & $2 \mathrm{M} \mathrm{VOSO}_{4}$ in $3 \mathrm{M} \mathrm{H}_{2} \mathrm{SO}_{4}$ & & 50 & \\
\hline & & $\sim 82$ & $\sim 97$ & & $0.8-1.65$ & 1 & 60 & 5 & $2 \mathrm{MVOSO}_{4}$ in $3 \mathrm{M} \mathrm{H}_{2} \mathrm{SO}_{4}$ & & 50 & \\
\hline & & $\sim 79$ & $\sim 97$ & & $0.8-1.65$ & 1 & 80 & 5 & $2 \mathrm{M} \mathrm{VOSO}_{4}$ in $3 \mathrm{M} \mathrm{H}_{2} \mathrm{SO}_{4}$ & & 50 & \\
\hline & & $\sim 75$ & $\sim 97$ & & $0.8-1.65$ & 1 & 100 & 5 & $2 \mathrm{M} \mathrm{VOSO}_{4}$ in $3 \mathrm{M} \mathrm{H}_{2} \mathrm{SO}_{4}$ & & 50 & \\
\hline \multirow[t]{2}{*}{16} & Caglar et al. $2014^{19}$ & $\sim 64$ & & & $0.8-1.6$ & 1 & $50(25-100)$ & 40 & & & 10 & \\
\hline & & -82 & & & & & & & & & & \\
\hline 18 & Lee et al. $2012^{17}$ & $\sim 76$ & $\sim 85$ & $\sim 90$ & $0.8-1.7$ & & 40 & & $2 \mathrm{M} \mathrm{VOSO}_{4}$ in $2.5 \mathrm{M} \mathrm{H}_{2} \mathrm{SO}_{4}$ & & 5 & \\
\hline \multirow[t]{4}{*}{19} & Qian et al. $2008^{47}$ & 81 & 89 & 91 & $0.8-1.75$ & 1 & 40 & & $1.5 \mathrm{M}$ vanadium in $3 \mathrm{M} \mathrm{H}_{2} \mathrm{SO}_{4}$ & 0.03 & 10 & \\
\hline & & 80 & 92 & 87 & $0.8-1.75$ & 1 & 60 & & $1.5 \mathrm{M}$ vanadium in $3 \mathrm{M} \mathrm{H}_{2} \mathrm{SO}_{4}$ & 0.03 & 10 & \\
\hline & & 79 & 93 & 85 & $0.8-1.75$ & 1 & 80 & & $1.5 \mathrm{M}$ vanadium in $3 \mathrm{M} \mathrm{H}_{2} \mathrm{SO}_{4}$ & 0.03 & 10 & \\
\hline & & 77 & 94 & 82 & $0.8-1.75$ & 1 & 100 & & $1.5 \mathrm{M}$ vanadium in $3 \mathrm{M} \mathrm{H}_{2} \mathrm{SO}_{4}$ & 0.03 & 10 & \\
\hline 20 & $\begin{array}{l}\text { Hagg \& Skyllas- } \\
\text { Kazacos } 2002^{23}\end{array}$ & 79 & 91 & $\begin{array}{l}80 / \\
86\end{array}$ & $0.8-1.8$ & 1 & 40 & & & & & \\
\hline \multirow[t]{3}{*}{21} & $\begin{array}{l}\text { Haddadi-Asl et al. } \\
1995^{16}\end{array}$ & & & 90 & & & 20 & 138 & $\begin{array}{c}2 \mathrm{M} \mathrm{V}^{4+} \text { in } 3 \mathrm{M} \mathrm{H}_{2} \mathrm{SO}_{4} / 2 \mathrm{M}, \mathrm{V}^{3+} \text { in } 2 \\
\mathrm{M} \mathrm{H}_{2} \mathrm{SO}_{4}\end{array}$ & & 20 & 23 \\
\hline & & & & 80 & & & 30 & 138 & $\begin{array}{c}2 \mathrm{M} \mathrm{V}^{4+} \text { in } 3 \mathrm{M} \mathrm{H}_{2} \mathrm{SO}_{4} / 2 \mathrm{M}, \mathrm{V}^{3+} \text { in } \\
2 \mathrm{M} \mathrm{H}_{2} \mathrm{SO}_{4}\end{array}$ & & 20 & 23 \\
\hline & & & & 75 & & & 40 & 138 & $\begin{array}{c}2 \mathrm{M} \mathrm{V}^{4+} \text { in } 3 \mathrm{M} \mathrm{H}_{2} \mathrm{SO}_{4} / 2 \mathrm{M}, \mathrm{V}^{3+} \text { in } 2 \\
\mathrm{M} \mathrm{H}_{2} \mathrm{SO}_{4}\end{array}$ & & 20 & 23 \\
\hline \multirow[t]{3}{*}{22} & $\begin{array}{l}\text { Kazacos \& Skyllas- } \\
\text { Kazacos } 1989^{4}\end{array}$ & 86 & 97 & 88 & & & 30 & & $2 \mathrm{M} \mathrm{VOSO}_{4}$ in $2 \mathrm{M} \mathrm{H}_{2} \mathrm{SO}_{4}$ & & $>50$ & 23 \\
\hline & & 83 & 93 & 89 & & & 30 & & $2 \mathrm{M} \mathrm{VOSO}_{4}$ in $2 \mathrm{M} \mathrm{H}_{2} \mathrm{SO}_{4}$ & & & 35 \\
\hline & & 85 & 94 & 90 & & & 30 & & $2 \mathrm{M} \mathrm{VOSO}_{4}$ in $2 \mathrm{M} \mathrm{H}_{2} \mathrm{SO}_{4}$ & & & 45 \\
\hline 25 & Liao et al. $2019^{31}$ & 85.7 & 96.7 & 88.6 & $0.8-1.65$ & 1 & $100(37.5,140)$ & 40 & $\begin{array}{c}1.5 \mathrm{M} \mathrm{V}^{2+} \text { in } 3.0 \mathrm{M} \mathrm{H}_{2} \mathrm{SO}_{4}, 1.5 \mathrm{M} \\
\mathrm{VO}_{2}^{+} \text {in } 3.0 \mathrm{M} \mathrm{H}_{2} \mathrm{SO}_{4}\end{array}$ & 0.07 & & \\
\hline 27 & Liao et al. $2020^{49}$ & 85.9 & 97.6 & 88.0 & $0.8-1.65$ & 1 & $100(37.5,140)$ & 40 & $\begin{array}{c}1.5 \mathrm{M} \mathrm{V}^{2+} \text { in } 3.0 \mathrm{M} \mathrm{H}_{2} \mathrm{SO}_{4}, 1.5 \mathrm{M} \\
\mathrm{VO}_{2}{ }^{+} \text {in } 3.0 \mathrm{M} \mathrm{H}_{2} \mathrm{SO}_{4}\end{array}$ & 0.07 & & \\
\hline 28 & Liu et al. $2018^{50}$ & & $\begin{array}{l}\sim 72 \\
-79\end{array}$ & $>80$ & $1-1.55$ & 1 & 40 & 24 & $\begin{array}{c}1.5 \mathrm{M} \text { vanadium sulfide in } 1.5 \mathrm{M} \\
\mathrm{H}_{2} \mathrm{SO}_{4}\end{array}$ & 0.15 & 4 & \\
\hline & Yang et al. $2017^{32}$ & 81.61 & 96.45 & 84.61 & $1-1.7$ & 1 & $80(120,160)$ & & & & 18 & \\
\hline \multirow[t]{2}{*}{30} & $\begin{array}{l}\text { Dongjiang et al. } \\
2020^{51}\end{array}$ & $\sim 80$ & & $\sim 84$ & $0.8-1.75$ & 1 & 50 & 10 & $\begin{array}{c}1.5 \mathrm{M} \mathrm{V}^{4+} \text { in } 3 \mathrm{M} \mathrm{H}_{2} \mathrm{SO}_{4}, 1.5 \mathrm{M} \mathrm{V}^{3+} \\
\text { in } 3 \mathrm{M} \mathrm{H}_{2} \mathrm{SO}_{4}\end{array}$ & 0.05 & $>100$ & \\
\hline & & $\sim 72$ & & $\sim 75$ & $0.8-1.75$ & 1 & 80 & 10 & & 0.05 & $>100$ & \\
\hline
\end{tabular}


Table VI. (Continued).

\begin{tabular}{|c|c|c|c|c|c|c|c|c|c|c|c|c|}
\hline No. & Literature & $\begin{array}{l}\mathrm{EE} \\
{[\%]}\end{array}$ & $\begin{array}{l}\mathrm{CE} \\
{[\%]}\end{array}$ & $\begin{array}{l}\mathrm{VE} \\
{[\%]}\end{array}$ & $\begin{array}{l}\text { Charge/discharge } \\
\text { voltage [V] }\end{array}$ & $\begin{array}{c}\text { Cell- } \\
\mathrm{s}\end{array}$ & $\begin{array}{l}\text { Current density } \\
{\left[\mathrm{mA} / \mathrm{cm}^{2}\right]}\end{array}$ & $\begin{array}{l}\text { Active area } \\
{\left[\mathrm{cm}^{2}\right]}\end{array}$ & Electrolyte & $\begin{array}{l}\text { Electrolyte } \\
\quad[\mathrm{L}]\end{array}$ & Cycles & $\mathrm{T}\left[{ }^{\circ} \mathrm{C}\right]$ \\
\hline \multirow{5}{*}{31} & \multirow{5}{*}{ Jiang et al. $2021^{28}$} & $\sim 66$ & & $\sim 67$ & $0.8-1.75$ & 1 & 100 & 10 & $\begin{array}{c}1.5 \mathrm{M} \mathrm{V}^{4+} \text { in } 3 \mathrm{M} \mathrm{H}_{2} \mathrm{SO}_{4}, 1.5 \mathrm{M} \mathrm{V}^{3+} \\
\text { in } 3 \mathrm{M} \mathrm{H}_{2} \mathrm{SO}_{4} \\
1.5 \mathrm{M} \mathrm{V}^{++} \text {in } 3 \mathrm{M} \mathrm{H}_{2} \mathrm{SO}_{4}, 1.5 \mathrm{M} \mathrm{V}^{3+} \\
\text { in } 3 \mathrm{M} \mathrm{H}_{2} \mathrm{SO}_{4}\end{array}$ & 0.05 & $>100$ & \\
\hline & & $\sim 51$ & & $\sim 53$ & $0.8-1.75$ & 1 & 150 & 10 & $\begin{array}{c}1.5 \mathrm{M} \mathrm{V}^{4+} \text { in } 3 \mathrm{M} \mathrm{H}_{2} \mathrm{SO}_{4}, 1.5 \mathrm{M} \mathrm{V}^{3+} \\
\text { in } 3 \mathrm{M} \mathrm{H}_{2} \mathrm{SO}_{4}\end{array}$ & 0.05 & $>100$ & \\
\hline & & 92.98 & & & $0.8-1.65$ & 1 & 40 & & $\begin{array}{c}1.5 \mathrm{M} \mathrm{VO}_{2}{ }^{+} \text {in } 3 \mathrm{M} \mathrm{H}_{2} \mathrm{SO}_{4}, 1.5 \mathrm{M} \\
\mathrm{V}^{2+} \text { in } 3 \mathrm{M} \mathrm{H}_{2} \mathrm{SO} 4\end{array}$ & 0.05 & 300 & \\
\hline & & 86.28 & & & $0.8-1.65$ & 1 & 100 & & $\begin{array}{c}1.5 \mathrm{M} \mathrm{VO}_{2}{ }^{+} \text {in } 3 \mathrm{M} \mathrm{H}_{2} \mathrm{SO}_{4}, 1.5 \mathrm{M} \\
\mathrm{V}^{2+} \text { in } 3 \mathrm{M} \mathrm{H}_{2} \mathrm{SO} 4\end{array}$ & 0.05 & 300 & \\
\hline & & 75.23 & & & $0.8-1.65$ & 1 & 200 & & $\begin{array}{c}1.5 \mathrm{M} \mathrm{VO}_{2}^{+} \text {in } 3 \mathrm{M} \mathrm{H}_{2} \mathrm{SO}_{4}, 1.5 \mathrm{M} \\
\mathrm{V}^{2+} \text { in } 3 \mathrm{M} \mathrm{H}_{2} \mathrm{SO} 4\end{array}$ & 0.05 & 300 & \\
\hline
\end{tabular}

a) these values seem to be too high for the respective electrolyte volume and could be typing errors. 
ions can behave aggressive and cause further damage to the carbonbased materials. ${ }^{71}$ Hence, the electrodes and BPPs might be susceptible to corrosion and suffer from carbon oxidation especially during cell overcharging in the positive half-cell. ${ }^{2,8,22,24,30,70,72,37}$ Since gas evolution at higher overpotentials can lead to irreversible erosion of carbon material, the corrosion of BPPs during overcharging in the positive half-cell is one major obstacle which has to be solved. ${ }^{27}$ In order to reduce side reactions the SOC of VRFBs is therefore usually limited to $80 \%-90 \%$ during charging. ${ }^{3,27}$

The degradation mechanisms and effects of various types of carbon materials differ from each other. Since composite BPPs are composed of more than one compound, each of them has its influence on the electrochemical stability and therefore different composite BPPs need to be investigated individually. Pretreatment of the same carbon material can result in varying oxygen-containing functional groups on the surface with different catalytic activities. ${ }^{73}$ For instance, on graphite particles the oxygen-containing functional groups are formed preferentially on the edge region than on the basal side. ${ }^{74}$ Besides graphite also other conductive minor fillers, such as carbon nanotubes or carbon black within BPPs are susceptible to corrosion. Especially carbon black fillers show unstable behavior during overcharging conditions. The reactive filler material can be oxidized and is then involved in side reactions that can lead to $\mathrm{CO}_{2}$ evolution and damage to the BPP composite matrix. ${ }^{2,23}$

In consequence of the construction of VRFBs there are two different types of current paths which can appear and affect arising undesired overpotentials. The first one is the main current path which transfers electrons and ions in through-plane direction across the stack (Fig. 6). It is supposed that the main current path does not play the decisive role in the corrosion of BPPs since the electrical potentials between the BPPs and the electrolyte solution are rather negligible in this case. The second one is the shunt current path that is acting as a by-pass ionic short circuit through the electrolyte solution within the fluid distribution manifolds between half-cells from adjacent cells in a stack (Fig. 6). Owing to the development of shunt currents, the electrical potential between the BPPs and the electrolyte may rise in comparison to the potentials in the main current path and generate high overpotentials leading to degradation of the composite BPPs. ${ }^{14,26,46,75}$ Especially the potential difference between the end (outmost) BPP and the positive half-cell electrolyte at high SOC may become abnormally large at the junction to the insulating frame and lead to corrosion at the edge of the BPP. ${ }^{24,75}$ Implementation of long and narrow channels between half-cells from adjacent cells can increase the ionic resistance and thus minimize the development and associated effects of shunt currents. However this would lead to an increase in pressure drop and higher consumption of pumping energy. ${ }^{75,76}$

In addition, there are further factors that can influence the development of unwanted overpotentials. Local electrical potential differences on the surface of BPPs can occur in in-plane direction as a result of changing SOC conditions within a half-cell during charging or discharging leading to SOC gradients (Fig. 7a). Thus, the electrons can also pass in in-plane direction along the BPPs. ${ }^{46}$ Moreover, when the electrolyte is circulated with a constant flow through the reaction unit, areas with different convection condition can occur due to uneven flow through the half-cell geometry. Stagnant/dead zones could develop at some local areas on the surfaces of electrodes and BPPs due to non-uniform electrolyte flow (Fig. 7b) ${ }^{77,78}$ Therefore, a carefully considered flow frame and stack design are important in order to provide uniform electrolyte flow distribution through each single cell in the stack. ${ }^{27}$ Moreover, if the BPPs are equipped with flow fields, the contact area between the electrodes and BPPs is reduced which results in an overall increased contact resistance. This leads to a heterogeneously distributed current density in conjunction with high local potential differences between the land and the flow channel regions. High potentials occur at the land edges and can lead to aging of the BPP material (Fig. 7c). ${ }^{61,79}$ In addition, inhomogeneous scattering of internal resistance due to unequal distribution of conductive composite material within the BPP can also lead to increase of potentials at local spots (Fig. 7d). Thus, it is important to provide uniform BPPs and to set a voltage limit for the charging mode. ${ }^{40}$

Mechanical damage-theoretical background.-In addition to the oxidation of the BPP surface through electrochemical corrosion, further damage can occur due to mechanical or other side effects. The formation of oxygen functional groups in the graphite structure can lead to weaker bonds between the single graphene layers and therefore to higher probability of exfoliation. ${ }^{26}$ Moreover, a direct consequence of $\mathrm{CO}$ and $\mathrm{CO}_{2}$ development is the erosion of carbon from the BPP material and a growing open pore network. ${ }^{38} \mathrm{~A}$ porous matrix in composite BPPs and in natural graphite plates leads to leakage paths through the material. Thus, during VRFB operation, sulphuric acid can intercalate in the graphene layers and enhance the exfoliation of graphite material. ${ }^{80}$ In addition, further mechanical damage can occur by using redox pairs with high negative and/or positive potentials, such as vanadium ions, which have an electrochemical activity in a similar potential range to hydrolysis. ${ }^{3,5,73}$ The water-splitting side reactions can occur during overcharging at high SOC in the aqueous electrolytes of the VRFB and lead to gas evolution. ${ }^{13,71}$ These side reactions might induce significant defects on the surface of BPPs. ${ }^{46}$ For instance, hydrogen evolution might occur during charging mode in the negative electrolyte since hydrogen development is directly competing with $\mathrm{V}^{3+}$ to $\mathrm{V}^{2+}$ reduction. ${ }^{27}$ In this case, the surface of BPPs can be damaged by blister development. ${ }^{46}$ In addition, the pressure of accumulating gas within the porous matrix of BPPs due to hydrolysis or $\mathrm{CO}_{2}$ development can lead to mechanical delamination of graphite layers or even to the formation of cracks and fractures in the bulk structure. $^{26,37}$ Single particles or carbon fibers from BPP and electrode material can break or be dispersed in the electrolyte. The pile-up of these particles within the half-cells can affect the electrolyte flow rate due to blocking of electrolyte channels or graphite felt pores which can lead to decreased electrolyte pumping efficiency through the half-cells and an overall higher risk of electrochemical degradation. ${ }^{17,24,26}$ Further corrosion can thereupon cause gas accumulation within the cell and cause interruption of local electrolyte flow followed by an increase of cell resistance with

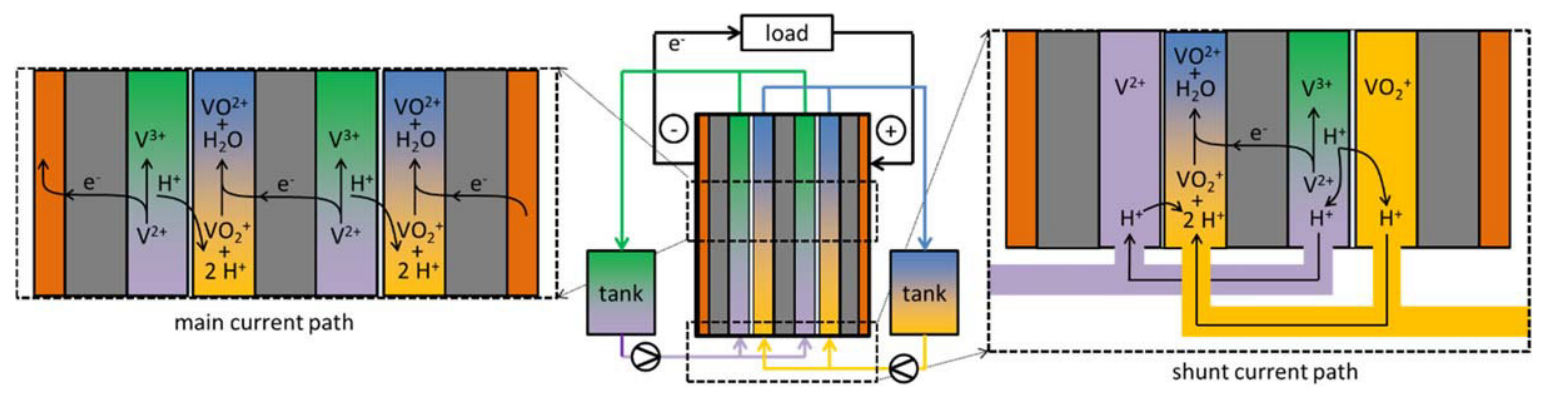

Figure 6. Schematic of the main and shunt current path in a VRFB. Image modified from sources. ${ }^{14,76}$ 
a) SOC difference

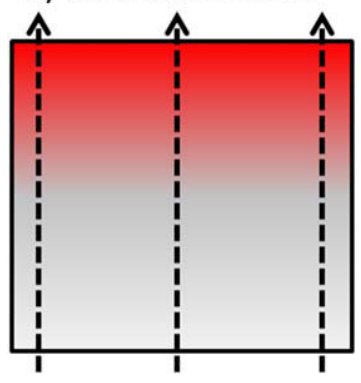

b) Stagnant zones

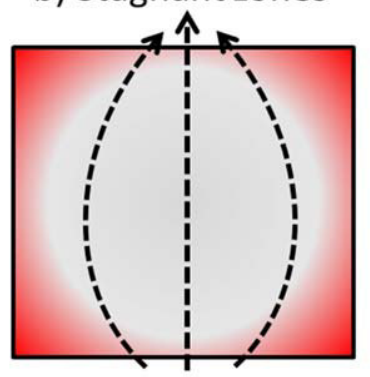

c) Flow field

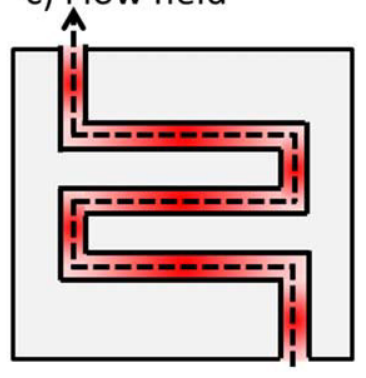

d) Unequal distribution

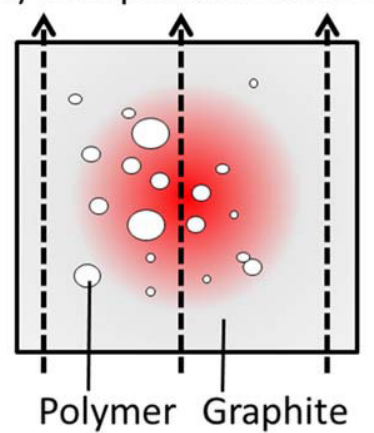

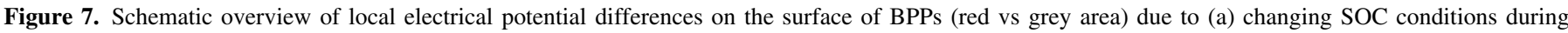

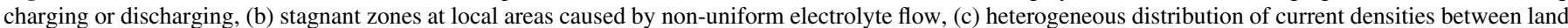
and channel regions of flow fields, (d) unequal distribution of polymer and conductive compound in the composite material.

the risk of further possible graphite oxidation in the positive half-cell. ${ }^{13}$ Hence, these effects influence each other and lead to a series of reactions.

Due to natural or corroded paths in the BPP the electrolyte can leak between adjacent cells and correspondingly to the metal current collector. If graphite plates break they can even cause accelerated leakage and corrosion of metal current collector material. ${ }^{80}$ Thus, in order to ensure a physical separation of adjacent cells, the BPPs need to be impervious, free of pin-holes and electrochemical stable. Otherwise the vanadium electrolyte could easily cause a short circuit while passing the BPP in through-plane direction, attack the metal current collector end plates or cause other leakages during battery operation. $^{16,52}$

Praxis examples of ex situ and in situ aging experiments.Aging experiments of BPPs in vanadium electrolyte can be divided into different categories, id est, chemical and electrochemical treatment. Chemical treatment covers simple immersion of samples in the electrolyte at varying temperatures, concentrations or SOC. Chemical treatment can be considered as investigation of resting state conditions of the battery where no charging or discharging occurs. ${ }^{39}$ Electrochemical treatments involve the application of galvanostatic/-dynamic or potentiostatic/-dynamic methods. Electrochemical measurements can be performed either ex-situ in an electrochemical cell or in situ in an assembled VRFB. Although corrosion effects of BPPs take place in VRFBs, they are not sufficiently characterized yet. Since corrosion can lead to substantial leakage problems, it is necessary to understand and investigate the corrosion mechanisms. ${ }^{30}$ Currently there is no standard procedure available for characterization of aging effects of BPPs. Quite the contrary is the case since each working group has its own investigation methods. In addition, some publications do not provide detailed information about the experimental procedures. That is why it is actually difficult to compare aging features and electrochemical stability of different carbon based BPP materials within literature. In this section, an overview of aging experiments is presented.

Chemical treatment.-Chemical stability of a BPP-felt assembly was measured by immersing the composite material in vanadium electrolyte with $4 \mathrm{M} \mathrm{H}_{2} \mathrm{SO}_{4}$ for $100 \mathrm{~h}$ at $80{ }^{\circ} \mathrm{C}$. A gas permeability test after treatment showed no gas flow through the material giving evidence for sufficient chemical stability of the composite material. ${ }^{45}$

In another approach, chemical stability of different BPPs containing a variety of minor and major fillers was tested in an electrolyte solution containing $\mathrm{VO}_{2}{ }^{+}$ions. The samples were immersed in the vanadium electrolyte at $80{ }^{\circ} \mathrm{C}$ for one week. Weight loss of $2 \%$ was observed for samples containing large graphite flakes of $80 \mu \mathrm{m}$ size. By introducing additional nanoparticles into the BPP and therefore increasing the voids within the matrix, the samples underwent a higher weight loss of even $6 \%$. BPPs with graphite flakes of $5 \mu \mathrm{m}$ size, exhibited a fracturing during treatment. Thus, smaller graphite particles are more susceptible to the acidic environment. ${ }^{20}$

Satola et al. $^{39}$ have performed a systematic study about the chemical stability of graphite-polypropylene composite BPPs. They immersed samples in the positive and negative vanadium electrolyte $\left(1.6 \mathrm{~mol} \mathrm{l}^{-1} \mathrm{~V}^{\mathrm{n}+}\right.$ in $2 \mathrm{~mol} \mathrm{l}^{-1} \mathrm{H}_{2} \mathrm{SO}_{4}$ and $\left.0.05 \mathrm{~mol}^{-1} \mathrm{H}_{3} \mathrm{PO}_{4}\right)$ with $0 \%, 20 \%, 80 \%$ and $100 \%$ SOC for up to $190 \mathrm{~d}$ at room temperature. The BPP showed satisfactory chemical stability in the negative electrolyte. However, under high SOC conditions in the positive electrolyte both graphite and polypropylene components of the composite material suffered from oxidation. Due to the changed hydrophilic properties of the surface the vanadium electrolyte could penetrate into the open pores of the BPP. However, the chemical treatment did not lead to any changes in morphology or electrical conductivity. ${ }^{39}$

Electrochemical ex situ treatment.-Electrochemical stability of BPPs was investigated in ex situ setups. Composite BPPs containing a graphite coating were treated in electrolyte containing $2.1 \mathrm{M} \mathrm{VO}^{2+}$ by applying $1.6 \mathrm{~V}$ and a current density of $20 \mathrm{~mA} \mathrm{~cm} \mathrm{~cm}^{-2}$ for one hour. After the electrochemical test the BPPs showed delamination effects of the graphite coating. Furthermore, visible cracks which were probably initiated during BPP fabrication technique develop further to larger cracks due to gas evolution from electrolysis side reactions. ${ }^{14}$ These initial cracks of the graphite coating layer might be closed and thus reduced by applying a compression pressure technique that leads to improved area surface conductivity. ${ }^{46}$

By performing ex situ cyclic voltammetry (CV) in vanadium electrolyte, BPPs with smaller graphite flakes showed increased oxygen evolution current density and thus a reduced electrochemical resistance than BPPs with flakes of larger size. This observation might be attributed to more active edges of smaller graphite particles which could lead to increased probability of side reactions. ${ }^{20}$

The corrosion resistance of a graphite/graphene/carbon fiberepoxy resin BPP was studied by potentiodynamic polarization and evaluation of Tafel plot. Liao et al. ${ }^{31}$ have found a corrosion

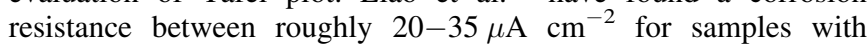
different contents of carbon materials which was in the range of a pure graphite BPP. ${ }^{31}$ However, no morphological analysis of the BPPs after the corrosion test was performed.

Liu et al. ${ }^{40}$ investigated the electrochemical stability of a carbonpolyethylene BPP in a three-electrode cell at $20{ }^{\circ} \mathrm{C}$ in $200 \mathrm{ml}$ electrolyte containing $2 \mathrm{M} \mathrm{H}_{2} \mathrm{SO}_{4}$ and $2 \mathrm{M} \mathrm{VOSO}_{4}$. Linear sweep voltammetry gave evidence for commencing $\mathrm{CO}_{2}, \mathrm{CO}$ and $\mathrm{O}_{2}$ gas evolution at $2 \mathrm{~V}$ vs saturated calomel electrode (SCE). A potentiostatic treatment was applied for $6 \mathrm{~h}$ at a potential of $2.5 \mathrm{~V}$ vs SCE. X-ray photoelectron (XP) spectroscopy revealed an increased amount and a higher variability of oxygen functional groups on 
the surface of the BPP after treatment, such as $\mathrm{R}-\mathrm{OH}, \mathrm{C}-\mathrm{O}-\mathrm{C}, \mathrm{C}=\mathrm{O}$ and $\mathrm{O}-\mathrm{C}-\mathrm{OH}$, which were introduced by oxidation of carbon. Liu et al. assumed that composite material is lost by oxidation of both carbon and polyethylene. Bulges and delamination became apparent due to strong gas evolution side reactions which lead to loss in mechanical strength that can result in electrolyte leakage through the composite material. $^{40}$

Satola et al. ${ }^{38}$ performed galvanodynamic cycling between -100 and $+100 \mathrm{~mA} \mathrm{~cm}{ }^{-2}$ for 3000 cycles within a three-electrode electrochemical cell. They used a graphite-polypropylene BPP as working electrode and the medium was the positive vanadium halfcell electrolyte $\left(1.6 \mathrm{~mol} \mathrm{l}^{-1} \mathrm{~V}^{\mathrm{n}+}\right.$ in $\left.2.1 \mathrm{~mol} \mathrm{l}^{-1} \mathrm{H}_{2} \mathrm{SO}_{4}\right)$ with $10 \%$, $50 \%$ and $90 \%$ SOC. The experiment was conducted in order to simulate charging and discharging conditions in a VRFB and to investigate the impact of the SOC window under polarization on the corrosion of the BPP. The cycling introduced new $\mathrm{C}-\mathrm{O}$ and $\mathrm{C}=\mathrm{O}$ oxygen functional groups on the surface of the BPP which were most pronounced after aging at high SOC. In addition, a rise in surface roughness was observed after treatment in $90 \%$ SOC electrolyte. Both factors led to a larger BPP/electrolyte interface and therefore became noticeable as an increase of double layer capacitance in the CV. Morphological analysis of the BPP bulk by means of micro computed tomography showed the propagation of open porosity into deeper regions up to $100 \mu \mathrm{m}$ after treatment with high SOC electrolyte. The round pore shapes of the open pore network gave evidence for oxidation of graphite and subsequent carbon erosion due to evolution of $\mathrm{CO}_{2}$ and/or $\mathrm{CO}$. While the open pore network was growing the electrolyte penetrated deeper into the composite structure and induced corrosion in the bulk of the BPP. However, the morphological changes did not affect the electrical conductivity of the samples. $^{38}$

In a further study Satola et al. ${ }^{37}$ proposed an aging mechanisms of graphite-polypropylene BPPs during harsh overcharging conditions of a VRFB. They applied high galvanostatic current densities $\left(+100 \mathrm{~mA} \mathrm{~cm}^{-12}\right.$ in the positive electrolyte and $-100 \mathrm{~mA} \mathrm{~cm}^{-12}$ in the negative electrolyte) on the BPP working electrode in a threeelectrode electrochemical cell for different time durations. The cell was filled with positive and negative vanadium electrolyte $(1.6 \mathrm{~mol}$ $1^{-1} \mathrm{~V}^{\mathrm{n}+}$ in $2.1 \mathrm{~mol} \mathrm{l}^{-1} \mathrm{H}_{2} \mathrm{SO}_{4}$ ), respectively, which was adjusted to $90 \%$ SOC. This experiment was performed in order to simulate the consequences of possible emergence of "dead zones", hindered electrolyte flow, or overcharging conditions of a VRFB which would be a worst case scenario during battery operation. Only negligible morphological changes and thus a good electrochemical stability of the BPP was observed after aging in the negative electrolyte, although massive hydrogen evolution occurred during treatment. However, treatment in the positive electrolyte led to serious damage of the composite material. The aging started with an oxidation of the BPP surface and subsequent carbon erosion due to $\mathrm{CO}_{2}$ and/or $\mathrm{CO}$ gas evolution. Micro computed tomography investigations showed an increase in open porosity and a formation of micro- and meso-cracks up to fractures as function of aging time. The cracks were oriented plane-parallel to the BPP/electrolyte interface in depth and it was observed that the corrosion front was propagating plane parallel to the back side of the samples. ${ }^{37}$

A low carbon content BPP containing a mixture of conductive carbon components was analyzed potentiodynamically between $-0.2 \mathrm{~V}$ to $0.5 \mathrm{~V}$ vs $\mathrm{Hg} / \mathrm{Hg}_{2} \mathrm{Cl}_{2}$ with $2 \mathrm{mV} \mathrm{s}^{-1}$ in a three-electrode electrochemical cell filled with $1.5 \mathrm{M} \mathrm{VOSO}_{4}$ in $3 \mathrm{M} \mathrm{H}_{2} \mathrm{SO}_{4}$. The analysis of the Tafel plot showed that the low carbon content BPP had a corrosion resistance comparable to a commercial graphite plate with $26 \mu \mathrm{A} \mathrm{cm}^{-2}$. 49

Electrochemical in situ treatment.-Kazacos and Skyllas-Kazacos ${ }^{4}$ performed in situ VRFB cycling using $2 \mathrm{M}$ vanadium sulphate in $3 \mathrm{M} \mathrm{H}_{2} \mathrm{SO}_{4}$ at $5{ }^{\circ} \mathrm{C}$. 50 cycles were performed between $0-2 \mathrm{~V}$ with a current density of $30 \mathrm{~mA} \mathrm{~cm}$. No performance degradation of carbon based BPPs and electrodes was observed. Graphite felts heat bonded to a graphite-polypropylene BPP showed good stability. However, in this paper they did not investigate the chemical surface characteristics, morphological structure or other alterations of the materials.

Also in newer publications, such as from Lim and Lee, ${ }^{45}$ in situ VRFB single cell charging/discharging test applying 100 cycles between 1.2-1.6 V showed no degradation of BPP-felt assemblies. However, similar to the aforementioned paper, no detailed information about the aging analysis were described.

Graphite BPPs show higher corrosion indications than composite BPPs after long-term cycling in a VRFB. The graphite corrosion is observed in the positive half-cell where oxidation of the surface occurs. While the degradation of graphite BPPs leads to electrolyte leakage and decline in efficiency or even to death of the battery, the composite BPP shows only slight bubble formation on the surface. This observation gives evidence that composite BPPs are more suitable for the application in VRFBs than graphite BPPs regarding their corrosion resistance. ${ }^{30}$

Duan et al. ${ }^{61}$ investigated the in situ aging of BPPs with and without flow field. Initially $1.5 \mathrm{M} \mathrm{VOSO}_{4}$ in $2 \mathrm{M} \mathrm{H}_{2} \mathrm{SO}_{4}$ was used as basis for preparation of the half-cell electrolyte solutions. Subsequent, charging/discharging tests were performed with cutoff voltages at $0.8 \mathrm{~V}$ and $2.0 \mathrm{~V}$. Pristine samples and those after 80 and 120 cycles were morphologically investigated. With higher cycling number the surfaces of the BPPs with and without flow field showed proceeding corrosion indications. They are characterized by development of rough surfaces. In case of the BPP with engraved flat field, the edges and corners of the land and channels disappear with longer cycling. In addition, an increase in oxygen functional groups is observed after cycling on both BPPs which gives evidence for carbon corrosion. ${ }^{61}$

\section{Economical View on Bipolar Plates}

Up to date VRFBs have still high capital costs and thus a commercialization is not given yet. ${ }^{81}$ The contribution of single components to the total cost of the VRFB is dependent on a series of factors such as available stack dimensions, electrolyte storage volume and operation parameters of the battery. Thus, there are costs that scale proportional to the power or the energy capacity, but some costs are independent of size. ${ }^{12}$ Generally, the costs of the electrolyte solutions tend to dominate with increasing energy/power ratio. On the other hand, the stack components are mainly contributing to the costs with higher power/energy ratio. ${ }^{82}$ Since the BPP is a repeatable component in a VRFB stack it is thus partly responsible for the arising areal costs of the reaction unit. ${ }^{73}$ Some publications indicate that the share of BPP costs is roughly $2 \%-8 \%$ of the total capital costs of a VRFB system with all its components or $4 \%-18 \%$ of only the VRFB stack. ${ }^{13,81-84}$ In a review paper about the economic assessment of current BPPs, Minke et al. ${ }^{85}$ listed the cost of BPPs between $37-418 € \mathrm{~m}^{-2}$ with an average of $100 €$ $\mathrm{m}^{-2}$. The price range is huge since the material constituents, plate geometries and manufacturing procedures are usually not specified in the different publications. ${ }^{85}$ Nevertheless, economic BPP optimization can give opportunities for cost reduction on average of $-50 \% .^{85,86}$

The most detailed study about the cost potentials of BPPs was performed by Minke et al. ${ }^{33}$ who have investigated three commercial BPPs (SIGRACET ${ }^{\circledR}$, Eisenhuth GmbH \& Co. KG, Germany) with graphite content of $\geqslant 80 \mathrm{wt} \%$ and different polymer types with a standard size of $625 \mathrm{~cm}^{2}$. PPG86 contains $14 \%$ polypropylene, BBP4 has $20 \%$ phenolic resin (PF) as binder material and BMA5 is composed of $20 \%$ PVDF polymer. The techno-economical approach is based on the raw material and manufacturing costs. It turned out that polypropylene $\left(\varnothing 1.20 € \mathrm{~kg}^{-1}\right)$ as binder material is more economical than PF ( $\left.\varnothing 1.40 € \mathrm{~kg}^{-1}\right)$ and PVDF $\left(\varnothing 14 € \mathrm{~kg}^{-1}\right)$ in terms of raw material costs. Thus, the BPP raw material and granulate preparation cost is about $8 € \mathrm{~kg}^{-1}$ for PPG86 and BPP4 and $15 € \mathrm{~kg}^{-1}$ for BMA5. The compounding cost is in average $60 \%$ 
of the total BPP cost. However, the different types of manufacturing processes have an impact on the total costs. Injection molding is more cost-effective than compression molding owing to the option of automated fabrication. Since only composites with special rheological properties and thermoplastic polymers are appropriate materials for injection molding, this manufacturing process is restricted to PPG86. Thus, from the three presented BPPs the PPG86 is the most economical favored plate. Up to date the market for BPPs is still very small. However, standardization and mass production harbors potential for cost reduction in the future. ${ }^{33}$ Currently, the active cell area of stacks is restricted to only $0.1 \mathrm{~m}^{2}$ owing to the limited manufacturing size of BPPs. However, upscaling of stacks with BPP dimensions of $2.7 \mathrm{~m}^{2}$ and a thickness of $7 \mathrm{~mm}$ by a new extrusion process have the potential for cost reduction of up to $-25 \%$ for the BPPs. ${ }^{87}$

\section{Summary and Outlook}

BPPs are essential components of the VRFB stack which provide substantial properties such as a good electrical conductivity, mechanical stability and impermeability in order to electrically connect and physically separate adjacent cells. Thus, BPPs enable to increase the battery voltage through the connection of cells in series. Different materials and construction designs for BPPs were investigated up to date. So far, the carbon based composite materials turned out to meet the best properties for the use in VRFBs. They combine a good compromise between electrical conductivity, mechanical stability and corrosion resistance.

Nevertheless, aging experiments have shown that composite BPPs might suffer from degradation processes, especially under conditions with highly charged positive vanadium electrolyte and/or by application of high voltage. Thus, it is recommended (I) to avoid storage of VRFBs at high SOC for long periods in order to prevent the oxidation of BPP surfaces, (II) to set voltage limits for the operation of VRFBs (such as $1.6 \mathrm{~V}$ for single cell batteries) and to avoid charging the battery to high SOC (e.g. above 80\%) and (III) guarantee a sufficient electrolyte distribution and flow through the reaction unit which are necessary conditions to prevent the local lack of reactive vanadium species and a triggered accelerated BPP degradation.

The literature review has shown that the comparison of BPPs and their properties is a challenge owing to varying characterization parameters and investigation methodologies that are applied in different publications. For instance, the electrical conductivities and the mechanical properties are influenced by many factors such as the sample size, the test speed or the compression pressure that are not kept constant in each case and that are sometimes not even mentioned within the experimental sections. Thus, a direct comparison of the BPPs' properties is quite impossible and rather results in an individual analysis of each BPP or the respective set of BPPs within a single paper. On the one hand it would be beneficial to develop and define standard investigation parameters and methods for the measurement of e.g. electrical conductivity, mechanical stability, permeability, efficiency and aging effects in order to facilitate a comparable study of BPP materials. On the other hand a standardization would probably lead to characterization limits for some samples owing to their specific individual properties. Further studies and development of BPPs could include a systematic preparation and comparable standardized investigation of diverse composite mixtures which could provide information about different material and composition properties and their applicability for the VRFB. For instance, different amounts and types of conductive additives, such as carbon black and carbon fiber, could influence the electrical conductivity but also modify the corrosion behavior of the composite materials. In addition, different polymer materials in the composite BPP could differ in strength or in swelling and aging behavior. In this context, it would be reasonable to investigate the chemical stability of single polymer compounds within a vanadium electrolyte solution which could be applied as binder in composite BPPs.

An important focus should be the development of composite materials that are suitable for the production of large BPPs in order to scale up VRFB stacks. These BPPs need to be mechanically flexible but still meet acceptable electrical conductivities. New approaches to develop low carbon content BPP with high flexural strength and preservation of good electrical conductivity properties meet these requirements. The construction of large BPPs could include an appropriate flow field design in order to provide a homogeneous distribution of electrolyte and minimize the development of shunt currents. Furthermore, the fabrication should also concentrate on low priced materials and manufacturing. Therefore, in conjunction with large applications, the next-generation construction design may include the development and enhancements of fused composite BPP-felt assemblies in order to keep a good electrical conductivity between both components in connection with a reduction of the compression force which could provide simplification of the industrial fabrication and stack assembling process. In addition, there is still a lack of studies about the aging behavior of large BPPs. They could provide information about the distribution of corrosion effects across the composite material within large-sized VRFB reaction units. A long term cycling of a VRFB stack would show if the BPP aging is the most critical factor of all aging processes within a VRFB stack and thus responsible for the battery lifetime. In this context, the micro computed tomography is a suitable method to investigate the $3 \mathrm{D}$ structure of BPPs including properties such as porosity, tortuosity and particle sizes which can be used to both evaluate the production quality and aging phenomena.

\section{Acknowledgments}

Excerpts of the present review paper are taken from the introduction of the author's $\mathrm{PhD}$ thesis (B. D. Satola, $\mathrm{PhD}$ thesis, Carl von Ossietzky Universität Oldenburg, 2019). The author appreciates the proofreading by Dr Lidiya Komsiyska, Dr Wiebke Germer and Marco Zobel. Additional thanks goes to Prof. Dr Gunther Wittstock for support and proofreading during the $\mathrm{PhD}$ time of the author. Dr Barbara Satola kindly acknowledges the Heinz Neumüller Stiftung and the Heinrich Böll Stiftung for endowment of two PhD scholarships. In addition, the author gratefully acknowledges financial support from the currently running project "IBiFi: research, Development and Evaluation of Fusion Methods for Realization of Integrated Bipolar Plate-Felt components for Redox-Flow-Batteries" from the Federal Ministry for Economic Affairs and Energy (BMWi, FKZ 03ET6136C).

\section{ORCID}

\section{Barbara Satola (iD https://orcid.org/0000-0002-5807-1763}

\section{References}

1. M. Skyllas-Kazacos, Encyclopedia of Electrochemical Power Sources, ed. J. Garche (Elsevier B.V., The Netherlands) 1st ed. (2009).

2. A. Parasuraman, T. M. Lim, C. Menictas, and M. Skyllas-Kazacos, Electrochim. Acta, 101, 27 (2013).

3. B. R. Chalamala, T. Soundappan, G. R. Fisher, M. R. Anstey, V. V. Viswanathan, and M. L. Perry, Proc. IEEE, 102, 976 (2014).

4. M. Kazacos and M. Skyllas-Kazacos, J. Electrochem. Soc., 136, 2759 (1989).

5. J. Noack, N. Roznyatovskaya, T. Herr, and P. Fischer, Angew. Chemie., 127, 9912 (2015).

6. P. Alotto, M. Guarnieri, and F. Moro, Renew. Sustain. Energy Rev., 29, 325 (2014)

7. A. M. Pezeshki, J. T. Clement, G. M. Veith, T. A. Zawodzinski, and M. M. Mench, J. Power Sources, 294, 333 (2015).

8. J. Winsberg, T. Hagemann, T. Janoschka, M. D. Hager, and U. S. Schubert, Angew. Chemie - Int. Ed., 56, 686 (2017).

9. T. Shibata, T. Kumamoto, Y. Nagaoka, K. Kawase, and K. Yano, SEI Tech. Rev., 76, 14 (2013).

10. T. Shigematsu, SEI Tech. Rev., 73, 4 (2011).

11. A. Z. Weber, M. M. Mench, J. P. Meyers, P. N. Ross, J. T. Gostick, and Q. Liu, J. Appl. Electrochem., 41, 1137 (2011).

12. M. Zhang, M. Moore, J. S. Watson, T. A. Zawodzinski, and R. M. Counce, J. Electrochem. Soc., 159, A1183 (2012) 
13. G. Kear, A. A. Shah, and F. C. Walsh, Int. J. Energy Res., 36, 1105 (2011).

14. K. H. Kim, B. G. Kim, and D. G. Lee, Compos. Struct., 109, 253 (2014).

15. S. Nam, D. Lee, D. G. Lee, and J. Kim, Compos. Struct., 159, 220 (2017).

16. V. Haddadi-Asl, M. Kazacos, and M. Skyllas-Kazacos, J. Appl. Electrochem., 25, 29 (1995).

17. N. J. Lee, S.-W. Lee, K. J. Kim, J.-H. Kim, M.-S. Park, G. Jeong, Y.-J. Kim, and D. Byun, Bull. Korean Chem. Soc., 33, 3589 (2012).

18. P. J. Hamilton and B. G. Pollet, Fuel Cells., 10, 489 (2010)

19. B. Caglar, P. Fischer, P. Kauranen, M. Karttunen, and P. Elsner, J. Power Sources, 256, 88 (2014)

20. M. Park, Y.-J. Jung, J. Ryu, and J. Cho, J. Mater. Chem. A, 2, 15808 (2014)

21. J. Han, H. Yoo, M. Kim, G. Lee, and J. Choi, Catal. Today, 295, 132 (2017).

22. M. Skyllas-Kazacos and F. Grossmith, J. Electrochem. Soc., 134, 2950 (1987)

23. C. M. Hagg and M. Skyllas-Kazacos, J. Appl. Electrochem., 32, 1063 (2002).

24. S. Rudolph, U. Schröder, I. M. Bayanov, and G. Pfeiffer, J. Electroanal. Chem., 709, 93 (2013).

25. W. Li, S. Jing, S. Wang, C. Wang, and X. Xie, Int. J. Hydrogen Energy, 41, 16240 (2016).

26. J. Choe, J. W. Lim, M. Kim, J. Kim, and D. G. Lee, Compos. Struct., 134, 106 (2015)

27. K. J. Kim, M.-S. Park, Y.-J. Kim, J. H. Kim, S. X. Dou, and M. Skyllas-Kazacos, J. Mater. Chem. A, 3, 16913 (2015).

28. F. Jiang, W. Liao, T. Ayukawa, S.-H. Yoon, K. Nakabayashi, and J. Miyawaki, J. Power Sources, 482, 228903 (2021)

29. B. Caglar, J. Richards, P. Fischer, and J. Tuebke, Adv. Mater. Lett., 5, 299 (2014)

30. J. Zhang, T. Zhou, L. Xia, C. Yuan, W. Zhang, and A. Zhang, J. Mater. Chem. A, 3, $2387(2015)$

31. W. Liao, Y. Zhang, X. Zhou, M. Zhuang, D. Guo, F. Jiang, and Q. Yu, ChemistrySelect., 4, 2421 (2019).

32. L. Yang, Y. Zhou, S. Wang, Y. Lin, T. Huang, and A. Yu, Int. J. Electrochem. Sci. 12, 7031 (2017)

33. C. Minke, T. Hickmann, A. R. dos Santos, U. Kunz, and T. Turek, J. Powe Sources, 305, 182 (2016).

34. T. Derieth, G. Bandlamudi, P. Beckhaus, C. Kreuz, F. Mahlendorf, and A. Heinzel, J. New Mat. Electrochem. Systems, 11, 21 (2008).

35. X. Cheng, Z. Shi, N. Glass, L. Zhang, J. Zhang, D. Song, Z.-S. Liu, H. Wang, and J. Shen, J. Power Sources, 165, 739 (2007).

36. D. Lee, J. Choe, S. Nam, J. W. Lim, I. Choi, and D. G. Lee, Compos. Struct., 160 976 (2017).

37. B. Satola, L. Komsiyska, and G. Wittstock, J. Electrochem. Soc., 165, A963 (2018)

38. B. Satola, L. Komsiyska, and G. Wittstock, J. Electrochem. Soc., 164, A2566 (2017).

39. B. Satola, C. Nunes Kirchner, L. Komsiyska, and G. Wittstock, J. Electrochem. Soc., 163, A2318 (2016)

40. H. Liu, L. Yang, Q. Xu, and C. Yan, RSC Adv., 5, 5928 (2015)

41. D. Lee, J. W. Lim, S. Nam, I. Choi, and D. G. Lee, Compos. Struct., 134, 1 (2015)

42. S. Nam, D. Lee, I. Choi, and D. G. Lee, Compos. Struct., 120, 107 (2015).

43. J. Choe, K. H. Kim, and D. G. Lee, Compos. Struct., 119, 534 (2015).

44. J. Choe, J. Kim, and D. G. Lee, Compos. Struct., 158, 333 (2016).

45. J. W. Lim and D. G. Lee, Compos. Struct., 134, 483 (2015).

46. K. H. Kim, J. Choe, S. Nam, B. G. Kim, and D. G. Lee, Compos. Struct., 119, 436 (2015).

47. P. Qian, H. Zhang, J. Chen, Y. Wen, Q. Luo, Z. Liu, D. You, and B. Yi, J. Power Sources, 175, 613 (2008)

48. D. Lee, D. G. Lee, and J. W. Lim, J. Intell. Mater. Syst. Struct., 29, 3386 (2018)

49. W. Liao, F. Jiang, Y. Zhang, X. Zhou, and Z. He, Renew. Energy., 152, 1310 (2020)

50. Z. Liu, B. Wang, and L. Yu, J. Energy Chem., 27, 1369 (2018)

51. Y. Dongjiang, L. Jingyuan, and K. Litao, Int. J. Energy Res., 44, 1920 (2020).

52. V. Haddadi-Asl, M. Kazacos, and M. Skyllas-Kazacos, J. Appl. Polym. Sci., 57, 1455 (1995)
53. P. Leung, X. Li, C. Ponce de León, L. Berlouis, C. T. J. Low, and F. C. Walsh, RSC Adv., 2, 10125 (2012)

54. A. Heinzel, F. Mahlendorf, O. Niemzig, and C. Kreuz, J. Power Sources, 131, 35 (2004)

55. D. J. L. Brett and N. P. Brandon, The Fuel Cell Review, 2, 15 (2005).

56. R. M. Darling and M. L. Perry, J. Electrochem. Soc., 161, A1381 (2014)

57. K. Lourenssen, J. Williams, F. Ahmadpour, R. Clemmer, and S. Tasnim, J. Energy Storage, 25, 100844 (2019).

58. C. R. Dennison, E. Agar, B. Akuzum, and E. C. Kumbur, J. Electrochem. Soc., 163 A5163 (2015)

59. Y. A. Gandomi, D. S. Aaron, J. R. Houser, M. C. Daugherty, J. T. Clement, A M. Pezeshki, T. Y. Ertugrul, D. P. Moseley, and M. M. Mench, J. Electrochem. Soc., 165, A970 (2018).

60. M. R. Gerhardt, A. A. Wong, and M. J. Aziz, J. Electrochem. Soc., 165, A2625 (2018).

61. Z. N. Duan, Z. G. Qu, Q. Wang, and J. J. Wang, Appl. Energy, 250, 1632 (2019).

62. S. Kumar and S. Jayanti, J. Power Sources, 307, 782 (2016).

63. A. Tang, J. Bao, and M. Skyllas-Kazacos, J. Power Sources, 248, 154 (2014).

64. Y. Zeng, F. Li, F. Lu, X. Zhou, Y. Yuan, X. Cao, and B. Xiang, Appl. Energy, 238 435 (2019)

65. M. A. Logan, Bell Syst. Tech. J., 40, 885 (1961).

66. L. J. Swartzendruber, National Bureau of Standards, Technical Note, 199, I (1964)

67. D. E Vaughan, Br. J. Appl. Phys. 12, 414 (1961).

68. R. Chen, S. Kim, and Z. Chang, Redox Flow Batteries: Fundamentals and Applications, Redox - Principles and Advanced Applications, ed. M. A. A. Khalid (IntechOpen, United Kingdom) (2017).

69. M. H. Chakrabarti, N. P. Brandon, S. A. Hajimolana, F. Tariq, V. Yufit, M A. Hashim, M. A. Hussain, C. T. J. Low, and P. V. Aravind, J. Power Sources, 253 150 (2014).

70. H. Liu, Q. Xu, and C. Yan, Electrochem Commun., 28, 58 (2013).

71. M. Skyllas-Kazacos, M. H. Chakrabarti, S. A. Hajimolana, F. S. Mjalli, and M. Saleem, J. Electrochem. Soc., 158, R55 (2011).

72. P. Trogadas, O. O. Taiwo, B. Tjaden, T. P. Neville, S. Yun, J. Parrondo, V. Ramani, M.-O. Coppens, D. J. L. Brett, and P. R. Shearing, Electrochem. Commun., 48, 155 (2014).

73. M. L. Perry and A. Z. Weber, J. Electrochem. Soc., 163, A5064 (2016)

74. N. Pour, D. G. Kwabi, T. Carney, R. M. Darling, M. L. Perry, and Y. Shao-Horn, J. Phys. Chem. C, 119, 5311 (2015).

75. R. M. Darling, H.-S. Shiau, A. Z. Weber, and M. L. Perry, J. Electrochem. Soc., 164, E3081 (2017).

76. M. Skyllas-Kazacos, J. McCann, Y. Li, J. Bao, and A. Tang, ChemistrySelect., 1, 2249 (2016).

77. C. Ponce de Leon, A. Friaa-Ferrer, J. Gonzalez-Garcia, D. A. Szanto, and F. C. Walsh, J. Power Sources, 160, 716 (2006)

78. R. E. W. Jansson and R. J. Marshall, Electrochim. Acta, 27, 823 (1982).

79. C. Yin, Y. Gao, S. Guo, and H. Tang, Energy, 74, 886 (2014).

80. J. Noack, L. Vorhauser, K. Pinkwart, and J. Tuebke, ECS Trans., 33, 3 (2011).

81. B. Zakeri and S. Syri, Renew. Sustain. Energy Rev., 42, 569 (2015).

82. A. Crawford, V. Viswanathan, D. Stephenson, W. Wang, E. Thomsen, D. Reed, B. Li, P. Balducci, M. Kintner-Meyer, and V. Sprenkle, J. Power Sources, 293, 388 (2015).

83. E. H. Mouron, The Economic Potential of the All-Vanadium Redox Flow Battery With a Focus on State of Charge, University Of Tennessee, Knoxville (2011), Chancellor's Honors Program Projects https://trace.tennessee.edu/utk_chanhonoproj/1421.

84. V. Viswanathan, A. Crawford, D. Stephenson, S. Kim, W. Wang, B. Li, G. Coffey, E. Thomsen, G. Graff, and P. Balducci et al., J. Power Sources, 247, 1040 (2014).

85. C. Minke and T. Turek, J. Power Sources, 376, 66 (2018).

86. G. L. Soloveichik, Chem. Rev., 115, 11533 (2015).

87. C. Minke, U. Kunz, and T. Turek, J. Power Sources, 361, 105 (2017). 